RIE ARIMURA

FACULTAD DE FILOSOFÍA Y LETRAS, UNAM

\title{
Las misiones católicas en Japón (1 549-1639): análisis de las fuentes y tendencias historiográficas
}

A Misión CATÓlica en Japón se inauguró con la llegada de Francisco Xavier en I549 y perduró hasta la consolidación de la política de

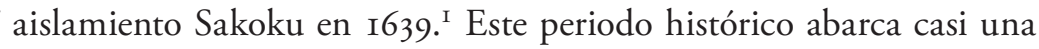
centuria y se le conoce como siglo kirishitan, dado que los japoneses así llamaron a los conversos, calificativo que derivaba del vocablo portugués cristão. Hoy día el concepto kirishitan designa en el ámbito religioso las creencias y prácticas católicas llevadas a cabo en el Japón moderno temprano. En las disciplinas de historia e historia del arte, las manifestaciones culturales y artísticas católicas de dicha centuria se abordan en el marco del estudio kirishitan o namban, "bárbaros del sur", término usado por los japoneses en aquel entonces para denominar a los portugueses y españoles que llegaban a la tierra del sol naciente a través del sur de Asia.

Para el estudio sobre la evangelización de dicho periodo, existen dos clases de fuentes primarias: occidentales y japonesas. Las primeras incluyen las cartas informativas, los anales y las crónicas que escribieron los misioneros con el fin de reportar las condiciones de las tierras locales, así como sus propias

I. El edicto de Sakoku, “cierre del país” (Sakoku-rei, 鎖国令), de I639, lo promulgó Tokugawa Iemitsu (I604-I65I), tercer shōgun de la dinastía Tokugawa, con el fin de eliminar la influencia católica y reforzar el régimen y la ideología de dicho shogunato. La vigencia de este decreto perduró hasta I853, ya que con la llegada del comodoro Matthew Perry, Japón se vio obligado a abrirse al mundo. 
labores religiosas. Estos escritos proyectan una concepción histórica basada en el providencialismo ${ }^{2}$ y la filosofía moralizante del bien y el mal; narran los acontecimientos de manera épica y alaban a los misioneros y a los mártires siguiendo la tradición hagiográfica medieval. Las segundas, las fuentes japonesas, se diversifican en cuanto al género, ya que abarcan los impresos jesuíticos llamados kirishitan-ban, que constan de textos doctrinales, lingüísticos y literarios, las defensas contra el cristianismo, la Biblia de los kakure kirishitan utilizada en el tiempo de persecuciones y los registros elaborados por las autoridades civiles en el periodo Edo, tales como el control de los antiguos kirishitan y sus descendientes y los inventarios de los objetos cristianos confiscados. Dado que las fuentes y la bibliografía sobre el tema son abundantes, en este ensayo se ha hecho una selección de las obras más relevantes para comprender las aproximaciones que se han realizado hasta ahora a fin de esclarecer el estado actual de la investigación.

\section{Aproximación "geoantropológica": postura jesuitica}

Las crónicas occidentales se distinguen grosso modo por dos vertientes historiográficas. La primera es de carácter llamado hoy "geoantropológico", en la que se registran el clima, la geografía, la política, la jerarquía social, la economía, la historia, las religiones, los ritos, las leyes, las costumbres y la idiosincrasia del pueblo japonés. La tradición de relatar la historia natural y moral proviene del legado literario de la Antigüedad. ${ }^{3}$ Las obras que pertenecen a esta corriente narrativa son principalmente fuentes escritas en el seno de la Compañía de Jesús, aunque no se puede generalizar sobre la historiografía jesuítica, puesto que el texto de Luis Pińeiro (I560-I620) trata exclusivamente las persecuciones y los martirios en Japón. ${ }^{4}$

2. El providencialismo es la doctrina según la cual todo sucede por disposición de la divina providencia. En las crónicas occidentales se observa una marcada insistencia en interpretar los acontecimientos históricos como parte de la voluntad de Dios.

3. Con relación a este asunto, cabe mencionar que el cronista jesuita José de Acosta (I540I60o) ha sido considerado el "Plinio del Nuevo Mundo" por fray Benito Jerónimo Feijoo en su Teatro crítico universal, escrito en I733. Al respecto, véase el prólogo de Edmundo O’Gorman al texto de José de Acosta, Historia natural y moral de las Indias, México, Fondo de Cultura Económica, 1962, p. XIII.

4. Luis Piñeiro, S.J., Relación del sucesso qve tuvo nuestra santa fe en los reynos del Iapon, 
Los jesuitas, formados en el ambiente humanista del Renacimiento, dieron importancia a conocer y comprender la cultura nativa y a que se optase por una política de evangelización acorde con las circunstancias locales. Dentro de esta corriente literaria destaca la História do Japão de Luís Fróis (I532-1597), 5 jesuita portugués que arribó a Japón en 1563 y se dedicó a actividades misioneras hasta el final de su vida en Kioto, Sakai, Bungo y Nagasaki. ${ }^{6}$ Este texto aporta datos relativos al contexto geográfico-cultural de Japón, así como a la expansión jesuítica realizada en aquellas tierras desde la etapa inicial de evangelización. Los registros sobre el establecimiento de sedes religiosas — tales como las negociaciones con las autoridades locales, los recursos materiales y humanos utilizados para las obras constructivas y las descripciones físicas-, así como la introducción y difusión de imágenes católicas y la creación de centros de estudios superiores — que incluían la escuela de arte fundada por Giovanni Nicolao-, dilucidan el entorno en que actuaron los misioneros, además de sus aportaciones sociales y culturales.

El uso de imágenes como método de evangelización se verifica ya desde el tiempo de Francisco Xavier, pues éste llevó consigo desde Europa pinturas al óleo de La Virgen con el Niño y La Anunciación. Del aprecio que tuvieron estas obras fue testigo el mismo santo en una de sus cartas: al mostrar una pintura de la Virgen al daimyō Shimazu Takahisa de Satsuma (I5I4-I57I), éste se quedó admirándola e incluso su madre quiso obtener una copia de ella, aunque no hubo quien supiera reproducirla. ${ }^{7}$ A partir de esta noticia, los cronistas destacaron los éxitos del arte católico entre los nativos. ${ }^{8}$ Ello también ha

desde el año de seyscientos y doze hasta el de seyscientos y quinze, imperando Cubosama, Madrid, impresa por la viuda de Alonso Martín de Balboa, i6r7.

5. Los escritos de Luís Fróis permanecieron inéditos durante varios siglos, ya que fueron descubiertos por Joseph Marie Cros, S.J., entre I894 y I895 en la colección Jesuitas na Asia de la Biblioteca Ajuda, en Lisboa. Estos textos se dieron a conocer ampliamente gracias a la publicación de Georg Schurhammer y Ernst Artur Voretzch, Die Geschichte Japans (I549-1578) von P. Luis Frois S.J. nach der Handschrift der Ajudabibliothek in Lissabon übersetzt und kommentiert von Georg Schurhammer und Ernst Artur Voretzsch, Leipzig, Verlag der Asia Major, pl. II, I926.

6. Georg Schurhammer, "Nihon-shi to chosha Luís Fróis", en Luís Fróis, Nihon-shi I: Kirishitan denrai no koro, Takeo Yanagiya (trad.), Tokio, Heibonsha, I973, pp. IO-I I.

7. The Letters and Instructions of Francis Xavier, Joseph Costelloe (trad. y ed.), St. Louis, Institute of Jesuit Sources, I992, p. 306.

8. Luis de Guzmán, Historia de las missiones que han hecho los religiosos de la Compañia de Iesvs para predicar el Sancto Evangelio en la India Oriental, y en los Reynos de la China y Iapon, Alcalá, impresa por la viuda de Juan Gracián, I6oI, vol. I, pp. 418-419. 
dejado un marcado impacto en la historiografía contemporánea. Así, los autores de nuestro tiempo han subrayado la gran aceptación que tuvo dicho arte en Japón, ${ }^{9}$ prescindiendo por completo de la recepción de los japoneses anticristianos, así como de las circunstancias en que se dieron las persecuciones.

Alessandro Valignano (I539-I606), en calidad de visitador de las Indias Orientales, viajó a Japón en tres ocasiones. Durante la primera estancia (I579I582), codificó una política misional de accommodatio de acuerdo con las etiquetas, los protocolos sociales y las tradiciones culturales de Japón, como muestran el Regimento para el Superior de Japón ${ }^{10}$ y los Advertimentos e avisos acerca dos costumes e catangues de Jappão (I58I). Para el estudio de la arquitectura kirishitan, esta última fuente es de suma relevancia, ya que en el capítulo VII se señalan sugerencias para las obras edificatorias de la Compañía de Jesús. Así, se reafirmó la importancia de aprovechar la capacidad y disponibilidad de los artífices japoneses y las tradiciones arquitectónicas locales. Para ello, se recomendó integrar un cuarto para la ceremonia de té y zashiki (salas de estar o de recepción), empleando materiales y soluciones constructivas nativas, además de respetar divisiones del espacio interior según las jerarquías sociales y los géneros. No obstante, Valignano mostró a su vez una actitud poco flexible en cuanto a la forma de las iglesias, puesto que éstas deberían construirse al modo europeo, introduciendo una planta oblonga. ${ }^{\text {I }}$

Esta primera visita dio también como fruto el Sumario de las cosas de Japón, obra que amplió en su segundo viaje (I590-1592) con una ańadidura titulada Adiciones del sumario de Japón. ${ }^{\mathrm{I2}}$ Asimismo, el tercer viaje (I598-I603) lo llevó a redactar la Apología de la Compañia de Jesús de Japón y de la China ${ }^{\mathrm{I3}}$ y Del

9. Tamon Miki, "The Influence of Western Culture in Japanese Art”, Monumenta Nipponica, vol. XIX, núms. 3-4, 1964, p. I46; Fernando García Gutiérrez, Japón y Occidente: influencias recíprocas en el arte, Sevilla, Guadalquivir, 1990, p. I67; Gauvin Alexander Bailey, Art on the Jesuit Missions in Asia and Latin America, I542-1773, University of Toronto Press, I999, pp. 59-60.

Io. Josef Franz Schütte, Valignano's Mission Principles for Japan, John J. Coyne (trad.), St. Louis, Institute of Jesuit Sources, 1980, vol. I [primera ed. I580].

II. Alejandro [Alessandro] Valignano, Il cerimoniale per i missionari del Giappone, Josef Franz Schütte (ed., introd. y notas), Roma, Edizione di "Storia e Letteratura”, 1946, pp. 273-28I.

I2. Alessandro Valignano, Sumario de las cosas de Japón [1583] y Adiciones del sumario de Japón [1592], José Luis Álvarez-Taladriz (ed.), Tokio, Universidad Sofía (Monumenta Nipponica Monographs, 9), I954, t. I.

13. Alejandro Valignano, Apología de la Compañia de Jesús de Japón y de la China, José Luis Álvarez-Taladriz (ed.), Osaka, s.e., I998 [primera ed. I598]. 
principio y progreso de la religión cristiana en Japón. ${ }^{\mathrm{I}}$ En estos escritos Valignano se aproximó a las costumbres japonesas equiparándolas con los valores culturales occidentales. De esta forma, aclaró diferencias entre los principios morales de Europa y Japón. Por otra parte, puso de manifiesto un discurso apologético a favor del monopolio de la Compañía de Jesús en Japón, lo que permite entrever los conflictos políticos entre órdenes religiosas en torno a la empresa evangélica en el Extremo Oriente.

Para el estudio de la historia del arte, la narrativa "geoantropológica" de los jesuitas aporta datos de gran interés. En efecto, se registran los materiales y las técnicas constructivas de la arquitectura vernácula, como residencias señoriales, monasterios budistas y casas ordinarias, y sus sistemas de proporción basados en el módulo de tatami, estera hecha de tejido de paja que tiene 8 palmos de largo y 4 de ancho $(176 \times 88 \mathrm{~cm}) .{ }^{15}$ Asimismo, se explican las artes liberales y mecánicas del Japón. Es decir, las primeras se sintetizan en el concepto de bumbunidō (文武二道, cultivar paralelamente las ciencias, las letras y las artes marciales). Respecto a las segundas, abordan distintas técnicas de pintura: iroe (色絵, pintura policroma), sumie (墨絵, pintura monocroma de tinta) y doroe o deie (泥絵, pintura con mezcla de lechada de cal), además del procedimiento para barnizar piezas de laca. ${ }^{16}$ Todo esto tiene importancia para el estudio del arte kirishitan, dado que de las tradiciones artísticas locales se aprovecharon no sólo los jesuitas sino también los mendicantes.

Las apreciaciones de los cronistas en torno a las imágenes católicas producidas por los japoneses descansaron sobre criterios eurocéntricos. Si las obras presentaban mayor similitud con las piezas occidentales eran altamente estimadas, como muestra la descripción de Fróis acerca de la escuela de arte en el seminario de Hachirao en I593:

No menos provecho están haciendo algunos de ellos tanto en la pintura, como en grabar láminas para la estampa: porque unos se ejercitan en pintar imágenes al óleo, de las cuales nos admiramos mucho, y porque otros de ellos toman del natural

I4. Alessandro Valignano, Del principio y progreso de la religión cristiana en Japón, British Library (I60I-I603), ms., additional MSS 9857, fol. i I.

I5. João Rodrigues Tçuzzu, S.J., "Do modo de edifficar dos japôes”, en História da igreja do Japão (I620-I633), 2 vols., transcripción del códice 49-IV-53 (ff. I-I8I) de la Biblioteca do Palácio da Ajuda, Lisboa, preparada por João do Amaral Abranches Pinto, Lisboa, Notícias de Macau, I954-I955, vol. I, lib. I, cap. I2.

I6. Ibidem, vol. II, pp. 6, I 4 у 2 I. 
algunas imágenes, de las más perfectas que trajeron de Roma los cuatro señores del Japón; con tanta perfección tanto en los colores, la nitidez y la sombra, como en las semejanzas, que después muchos padres y hermanos no sabían distinguir cuáles eran las que hicieron ellos y cuáles fueron hechas en Roma. ${ }^{17}$

Esta alabanza a la capacidad de los japoneses para reproducir las obras europeas era un recurso retórico para exaltar la efectividad de las labores educativas de la Compañía de Jesús. Empero, al mismo tiempo, esta postura eurocéntrica hizo que se descalificara el arte kirishitan, ya que Pedro Gómez mencionó en una carta fechada en I599: "los estudiantes de arte, a pesar de su gran capacidad imitativa, no tienen originalidad al producir sus obras". ${ }^{18}$ A este respecto cabe agregar que, a diferencia de Europa, en la tradición japonesa el concepto de "originalidad" no era cualidad positiva de una obra, toda vez que el original y la copia tenían el mismo valor artístico. Además, ir de acuerdo con los cánones establecidos era tan importante que si no se respetaban se quitaba a los pintores el derecho a ejercer su profesión. ${ }^{19}$ De tomar en cuenta el contexto cultural, cabe cuestionar los juicios eurocéntricos.

Por lo que toca a las fundaciones jesuíticas, además de Fróis, otros autores como Valignano y Guerreiro (ca. I550-I6I7) dieron datos históricos y sus descripciones: señalaron el patrocinio, el aprovechamiento de los recintos budistas, la reutilización de los materiales constructivos, la manera como adaptaron la arquitectura nativa o cómo introdujeron elementos europeos, además de aludir a la comodidad, capacidad y proporción de los edificios. ${ }^{20}$ Esta información proporcionada por los sacerdotes que conocieron Japón se puede con-

17. Luís Fróis, Historia de Japam, José Wicki (ed.), S.J., Lisboa, Biblioteca Nacional de Lisboa, I 984, vol. V (I 588-I 593), pp. 479-480: "Não menos proveito vão fazendo alguns delles assim em pintar, como em abrir laminas para estampa: porque huns se exercitáo em pintar imagens de oleos, os quaes nos fazem grandemente admirar, porque alguns delles tirão pelo natural algumas imagens das mais perfeitas que trouxerão de Roma os quarto fidalgos japóes, com tanta perfeição assim das cores, nitidez e sombras, como das similhanças, que depoes entre os Padres e Irmáos muitos não sabião dixtinguir quaes erão as que elles fizerão, e quaes as que forão feitas em Roma."

I8. Pedro Gómez, citado por García Gutiérrez, op. cit., p. I68.

19. Okakura Tenshin, "Tōyō no risō" [The Ideals of the East, 1904], en Okakura Tenshin$s h \bar{u}$, Takeshi Umehara (ed.), Tokio, Chikuma Shobō, I976, pp. 73-74.

20. Valignano, Sumario de las cosas de Japón..., op. cit., p. 84; Fernão Guerreiro, Relação anual das coisas que fizeram os padres da Companhia de Jesus nas suas missóes do Japão, China..., Coimbra, Imprensa da Universidade, I930, t. I, pp. I79-I80 [primera ed. Lisboa, I600-I609]. 
siderar fidedigna, a diferencia del Compendio delle heroiche et gloriose attioni, et santa vita di papa Greg. XIII de Ciappi ${ }^{21}$ que es fruto del imaginario europeo, como se ahondará más adelante.

La corriente literaria "geoantropológica" de la Compañía de Jesús, no obstante, llegó a su fin con los fracasos definitivos de evangelización en Japón. Así, Daniello Bartoli (I608-I685), autor de la monumental obra Dell'istoria della Compagnia di Gesù... (1650-1673), dedicó un volumen a las misiones en Japón. A diferencia de los cronistas del siglo Xvi y principios del XVII, no mostró interés por tratar ampliamente la geografía y la cultura de Japón, sino que recopiló extensos datos sobre las labores jesuíticas en aquella tierra para legitimar una historia oficial de la Compañía de Jesús. ${ }^{22}$

\section{Retórica de la orden religiosa: narraciones mendicantes}

Los escritos de las órdenes mendicantes, que constituyen la segunda vertiente historiográfica de las crónicas occidentales, enfocan en mayor medida asuntos relacionados con su propia orden: las actividades religiosas y sociales, la biografía de los misioneros y las alabanzas a los mártires, sin extender lo natural, lo político-social y lo moral-religioso de la cultura nativa. En efecto, Marcelo de Ribadeneira (m. ca. I6Io), autor de la Historia de las islas del archipiélago filipino y reinos de la gran China, Tartaria, Cochinchina, Malaca, Siam, Cambodge y Japón, ${ }^{23}$ así como José Sicardo (I643-1715), autor de la Christiandad del Japón y dilatada persecvcion que padecio... (I698), ${ }^{24}$ dedican sólo un capítulo con el título de "Descripción del reino de Japón” para relatar asuntos locales. Lo anterior

2I. Marco Antonio Ciappi, Compendio delle heroiche et gloriose attioni, et santa vita di papa Greg. XIII, Roma, Stamperia degli Accolti, I596, pp. 39-40.

22. Daniello Bartoli, Dell'istoria della Compagnia di Gesù. Il Giappone, seconda parte dell'Asia, Turín, Giacinto Marietti, I825 [primera ed. Turín, I667]; Giappone: istoria della Compagnia di Gesù, Nino Majellaro (ed.), Milán, Spirali, I985.

23. Marcelo de Ribadeneira, O.F.M., "Descripción del reino de Japón”, en Historia de las islas del archipiélago filipino y reinos de la gran China, Tartaria, Cochinchina, Malaca, Siam, Cambodge y Japón, Juan R. de Legísima (ed., pról. y notas), Madrid, Católica, I947, lib. IV, cap. I [primera ed. Barcelona, I6oI].

24. José Sicardo, O.S.A., dedica sólo un capítulo para hablar de la sociedad japonesa, "Descripción del reyno del Japón", en Christiandad del Japón y dilatada persecvcion que padecio. Memorias sacras de los martyres de las ilvstres religiones de Santo Domingo, San Francisco, Compañia de Jesus; y crecido numero de seglares: Y con especialidad, de los Religiosos del Orden de 
se debe a que la intención principal de estos autores consistía en tratar el martirio de los frailes de su orden, como afirma Ribadeneira. ${ }^{25}$

Con todo, en el ámbito universal, la aproximación "geoantropológica" no fue exclusiva de las crónicas jesuíticas. Baste citar a Bernardino de Sahagún, O.F.M. (ca. I500-1590), en América, y a Juan González de Mendoza, O.S.A. (I545-I6I8), en China, quienes dejaron textos de tal naturaleza, ${ }^{26}$ aunque el segundo autor nunca estuvo en China. En ese sentido, hubo una diferencia notable en cuanto a las fuentes utilizadas entre los cronistas que conocieron directamente el lugar y los que se basaron en las interpretaciones hechas por otros autores. La ausencia de escritos mendicantes que traten de manera amplia la cultura japonesa se debe a las circunstancias históricas. En parte, cuando los frailes llegaron a las tierras japonesas, los jesuitas habían llevado a cabo la empresa misionera desde hacía medio siglo y ya se habían realizado de manera exhaustiva estudios geográficos, culturales y lingüísticos sobre Japón. Además, a los mendicantes les tocó vivir las persecuciones poco después de su llegada, lo cual impidió que escribieran compendios de tal naturaleza, que requieren años de investigación.

La documentación y las crónicas de las órdenes franciscana y dominica sobre las misiones de Japón proceden, respectivamente, de la provincia de San Gregorio y la del Santo Rosario, ambas en Filipinas. Respecto a las fuentes agustinas, se trata de escritos de los autores novohispanos, lo que indica el estrecho vínculo político-religioso entre América y Asia. En efecto, Juan de Grijalva (I580-I638) aborda los procesos de la expansión española hacia el Extremo Oriente, presentando a los agustinos como pioneros de la evangelización en aquellas tierras, ${ }^{27}$ mientras que Diego Basalenque (I577-165I), José Sicardo (I643-I7I5) y Matías de Escobar (I690-I748) relatan la misión de su orden en Japón ensalzando la historia de los martirios.

N.P.S. Augustin, Cambridge, Massachusetts, General Microfilm, I999, lib. I, cap. I [primera ed. Madrid, Francisco Sanz, impressor del reyno, I698].

25. Ribadeneira, op. cit., p. 322.

26. Bernardino de Sahagún, Historia general de las cosas de Nueva España, México, Porrúa (Sepan Cuántos..., 300), 1997; Juan González de Mendoza, Historia de las cosas más notables, ritos y costumbres del gran reino de la China, Félix García, O.S.A. (pról. y notas), Madrid, M. Aguilar, ca. 1944, cap. I [primera ed. Roma, I585].

27. Juan de Grijalva, Crónica de la orden de N.P.S. Agustín en las provincias de la Nueva España, en cuatro edades desde el año de 1533 hasta el de 1592, México, Porrúa, 1985, pp. I20 y ss. y 260 y ss. [primera ed. México, I624]. 
Con respecto a la relación entre la Nueva España y Asia, vale la pena señalar que las provincias franciscanas del Santo Evangelio de México y de San Pedro y San Pablo de Michoacán, así como la provincia agustina de San Nicolás de Tolentino de Michoacán, eran estancias importantes para la comunicación entre América y Asia. ${ }^{28}$ Incluso, Domingo Martínez menciona que el mártir fray Luis de San Francisco, natural de Japón, tomó el hábito y profesó en la provincia franciscana de Michoacán y finalmente lo sacó de dicha provincia fray Luis Sotelo con el fin de integrarlo a la misión de Japón. ${ }^{29} \mathrm{Si}$ bien los pioneros de la evangelización mendicante en Oriente fueron los agustinos, éstos optaron en un principio por quedarse a trabajar en Filipinas. Por ende, los primeros frailes que hicieron negociaciones directas con las autoridades japonesas y abrieron el campo de misión mendicante en Japón no fueron agustinos, sino franciscanos.

Fuentes franciscanas

Entre la documentación más antigua sobre las misiones franciscanas en Japón están las cartas y relaciones de san Pedro Bautista (I542-I597), pionero y comisario de las mismas. Sus escritos abordan ciertas diferencias entre los jesuitas y los franciscanos, así como el avance de las labores evangélicas en aquella tierra. ${ }^{30}$ También cabe mencionar los Testimonios authenticos de los originales de todas las diligencias que hizo la religión seraphica de la Santa Provincia de Philipinas acerca del martirio de los santos san Pedro Baptista y sus compañeros prothomartyres del Japón. ${ }^{3 \mathrm{I}}$ Este corpus documental de procedencia filipina fue

28. Domingo Martínez, Compendio histórico de la apostólica provincia de San Gregorio de Philipinas de religiosos menores descalzos de N.P. San Francisco, en que se declaran sus heroycas empressas, para la dilatación de nuestra santa fé por varios reynos, y provincias del Assia..., Madrid, Imprenta de la viuda de Manuel Fernández y del Supremo Consejo de la Inquisición, I756, pp. 79 y I6I; Matías de Escobar, Americana Thebaida. Vitas Patrum de los religiosos hermitaños de N.P. San Agustin de la provincia de San Nicolás Tolentino de Mechoacán, México, Imprenta Victoria, 1924 [primera ed. 1729].

29. Martínez, op. cit., p. 208.

30. Las cartas y relaciones de san Pedro Bautista forman parte del acervo del Archivo General de Indias, Sevilla, y la Biblioteca Nacional de España, Madrid, y fueron publicadas por Lorenzo Pérez, "Cartas y relaciones del Japón”, en Archivo Ibero-Americano, t. IV-XIX, I915-1923.

31. Testimonios authenticos de los originales de todas las diligencias que hizo la religión seraphica de la Santa Provincia de Philipinas acerca del martirio de los santos san Pedro Baptista y sus compañeros prothomartyres del Japón, México, s.e., I954. 
enviado a la Nueva Espańa para promover el culto universal de los 26 mártires en Nagasaki el 5 de febrero de 1597, por lo que llegó a pertenecer al archivo del convento de San Francisco, en la ciudad de México. Para este estudio, la importancia de esta fuente consiste en aclarar los procesos de la empresa político-religiosa de la Corona española en Asia, en especial los esfuerzos diplomáticos que se hicieron sin contar con permiso papal para abrir el campo de evangelización en Japón.

Asimismo, Marcelo de Ribadeneira, descalzo español que recorrió diversas regiones de Asia y estuvo en Japón entre 1594 y I596, ahondó en la complejidad política de las primeras penetraciones franciscanas en tierra japonesa en su Historia de las islas del archipiélago filipino y reinos de la gran China, Tartaria, Cochinchina, Malaca, Siam, Cambodge y Japón (I601). El breve de Gregorio XIII no permitía la entrada de ningún religioso al Japón, salvo los jesuitas. Ante esta situación, la ida de fray Pedro Bautista a aquella tierra, aunque fuera en calidad de embajador del gobierno filipino, implicaba una gran contradicción. ${ }^{32}$ Empero, Ribadeneira relata cómo los frailes realizaron negociaciones con las autoridades locales y establecieron sus fundaciones, además de la vida y martirio de los frailes de su orden. ${ }^{33}$

Esta última obra sirvió de fuente para otros escritos posteriores, ya que la Chronica de la provincia de San Joseph de los descalços de la Orden de los Menores de Nuestro Seraphico Padre San Francisco (I615-1618) de Juan de Santa María (m. I622) presenta semejanzas en el contenido. Así, respecto a la arquitectura franciscana, ambos autores califican los conventos y las iglesias de Kioto y Osaka "a modo de los conventos de los Descalzos de Castilla" 34 o "a nuestro modo", 35 mientras que los hospitales y la escuela en Kioto se realizaron "a modo de Japón", ${ }^{6}$ lo que sugiere que la introducción de soluciones occidentales se limitó a las construcciones con función litúrgica y religiosa.

32. Ribadeneira, op. cit., p. 33 I.

33. Ibidem, pp. 340 y 342.

34. Así califica Ribadeneira a la iglesia de Santa María de los Ángeles de Kioto, mientras que Juan de Santa María considera el mismo edificio de "todo a la traça, y medida de los conventos de los Descalços de San Joseph de España”, en Ribadeneira, op. cit., p. 342; Juan de Santa María, Chronica de la provincia de San Joseph de los descalços de la Orden de los Menores de Nuestro Seraphico Padre San Francisco, Madrid, Imprenta Real, I6I8, vol. II, p. 4I.

35. Santa María, op. cit., vol. II, p. I82.

36. Ribadeneira, op. cit., p. 355; Santa María, op. cit., vol. II, p. 5 I. 
Por lo que toca a las persecuciones y los martirios, las cartas y relaciones que escribió Diego de San Francisco — que arribó a Japón a finales de i6r i o principios de 1612- son una fuente de peso, ya que aclaran no sólo las causas, sino también cómo esta política anticristiana afectó las fundaciones y las labores franciscanas principalmente en la actual región de Kantō y Nagasaki. ${ }^{37}$

En el siglo XviII, Juan Francisco de San Antonio, en sus Chronicas de la apostólica provincia de S. Gregorio de religiosos descalzos de N.S.P.S. Francisco en las islas philipinas, China, Japón, \&oc. ${ }^{38}$ aportó noticias relativas a la presencia de los japoneses dentro y fuera de Manila, ${ }^{39}$ de tal forma que señaló el interés de las autoridades civiles y religiosas de Filipinas en los comerciantes japoneses cristianizados que llegaban a Manila para realizar una apertura comercial y la evangelización en aquella tierra. ${ }^{40}$

Asimismo, este tema relativo a la vivencia que tuvieron los frailes con los japoneses en Filipinas fue ampliado por Domingo Martínez en su Compendio histórico de la apostólica provincia de San Gregorio de Philipinas de religiosos menores descalzos de N.P. San Francisco... En esta obra, el autor dilucidó la política y el plan misional en el Extremo Oriente, ya que se planeó convertir Manila en el lugar de capacitación para las próximas misiones en otros países asiáticos. Para el proyecto misional de Japón, se propuso "que la provincia diesse un convento cerca de Manila, en que los dichos religiosos morassen y aprendiessen lengua japona". ${ }^{\text {I }}$ Por ende, en el pueblo de Dilao, cerca de Manila, se estableció un centro donde los frailes pudiesen convivir con los japoneses que radicaban en Filipinas y aprendiesen no sólo el idioma, sino también la idiosincrasia y las costumbres japonesas, como parte de la preparación para emprender las labores apostólicas en Japón. De igual modo, el autor registró datos sobre las fundaciones, las obras evangélicas y las atenciones médicas que realizaron los franciscanos en la tierra en cuestión.

37. Lorenzo Pérez, O.F.M. (ed.), Relaciones de Fr. Diego de San Francisco sobre las persecuciones del cristianismo en el Japón (1625-1632), Madrid, Gabriel López del Horno, I9I4; Diego de San Francisco hōkoku shokan-shü, Tadashi Sakuma (trad.), Tokio, Kirishitan Bunka Kenkyūkai, I97I.

38. Juan Francisco de San Antonio, Chronicas de la apostólica provincia de S. Gregorio de religiosos descalzos de N.S.P.S. Francisco en las islas philipinas, China, Japón, Erc., Manila, Imprenta del convento de Nuestra Señora de Loreto del pueblo de Sampaloc, I738-I74I, vols. I-II.

39. Ibidem, vol. I, p. I79.

40. Ibidem, vol. II, p. I82.

4I. Martínez, op. cit., p. I65. 


\section{Fuentes dominicas}

Por lo que toca a la documentación dominica, existen las cartas y las relaciones escritas por los beatos Francisco Morales (I567-I622), José de San Jacinto Salvanés (I580-I622), Alonso de Mena (I578-I622), Jacinto Orfanell (I578I622) y Tomás del Espíritu Santo de Zumárraga (I577-I622), que fueron a Japón y murieron martirizados. ${ }^{42}$ Estos documentos presentan datos relativos a las negociaciones con las autoridades locales y al estado de cristianización, y además describen la manera como se adaptaron al modus vivendi de los japoneses, ya que por mucho que se esforzasen en respetar las reglas de su orden, había necesidad de acomodarse a las circunstancias locales. ${ }^{43}$ Este hecho induce a poner en tela de juicio la idea legitimada del siglo xx de reconocer sólo la accommodatio de los jesuitas.

Entre las crónicas dominicas cabe destacar la obra del beato Orfanell, Historia ecclesiastica de los sucessos de la christiandad de Iapon: desde el año I602, que entró en él la orden de predicadores hasta el de I620. En ella se registraban de manera detallada las características topográficas y arquitectónicas de las fundaciones dominicas, así como los procesos de evangelización en el territorio japonés. ${ }^{44}$ Francisco Carrero, vicario de Binondo, por su parte, escribió el Triunfo del Santo Rosario y Orden de Santo Domingo en los reinos del Japón desde el año del Señor I6I7 hasta el de I624 para rendir homenaje a los mártires de su orden. ${ }^{45}$

42. Estos manuscritos estuvieron bajo custodia del Antiguo Archivo del Santo Rosario en Manila y fueron sacados a luz por José Delgado García, O.P. — quien estuvo a cargo de la edición y notas — en las décadas de 1970-1990 — la traducción la llevó a cabo Tadashi Sakuma—: Fukusha Francisco Morales, O.P., Shokan hōkoku, Tokio, Kirishitan Bunka Kenkyūkai, I972; Fukusha José de San Jacinto Salvanés, O.P., Shokan hōkoku, Tokio, Kirishitan Bunka Kenkyūkai, 1976; Fukusha Alonso de Mena, O.P., Shokan hōkoku, Tokio, Kirishitan Bunka Kenkyūkai, I982; Fukusha Jacinto Orfanell, O.P., Shokan hōkoku, Tokio, Kirishitan Bunka Kenkyūkai, I983; Fukusha Tomás del Espíritu Santo de Zumárraga, O.P., Shokan hōkoku, Tokio, Kirishitan Bunka Kenkyūkai, I984; Cartas y relaciones del beato José de San Jacinto Salvanés, O.P., misionero y mártir del Japón, Madrid, Secretariado de Misiones Dominicanas, 1996.

43. Morales, op. cit., p. 28.

44. Jacinto Orfanell, Historia ecclesiastica de los sucessos de la christiandad de Iapon: desde el año 1602, que entró en él la orden de predicadores hasta el de 1620, Madrid, impreso por la viuda de Alonso Martín, I633.

45. Francisco Carrero, O.P., Triunfo del Santo Rosario y Orden de Santo Domingo en los reinos del Japón desde el año del Señor I6I7 hasta el de I624, $3^{\mathrm{a}}$ ed., José Delgado, O.P. (introd. y 
Asimismo, cabe destacar la figura del padre Diego Collado, O.P. (m. 1638), quien se incorporó en las misiones de Japón en I6r9, en pleno momento de persecuciones. Collado es prueba de que las aportaciones en el campo lingüístico no fueron exclusivas de los jesuitas, ya que, con el apoyo de la Congregatio pro Gentium Evangelisatione, publicó Ars grammaticae iaponicae linguae (I632) ${ }^{46}$ y los textos de catecismo dirigidos a los padres en japonés y latín: Niffon no cotöbani yô confesion.../Modus confitendi et examinandi... ${ }^{47}$ Estas obras sugieren que hubo intención de restablecer las misiones en Japón, lo cual no llegó a concretarse.

Diego de Aduarte (I569-I639), obispo de la Nueva Segovia, escribió las relaciones sobre los martirios de la orden dominica en Japón entre I626 y I628.48 Asimismo, en su Historia de la provincia del Santo Rosario de la orden de predicadores en Filipinas, Japón y China, abordó las dificultades que tuvieron los frailes en aquella tierra, ya que continuaron las labores adaptando provisionalmente las casas de los conversos como espacio litúrgico. ${ }^{49}$ Por otra parte, la difícil situación de los católicos hizo que los religiosos de las tres órdenes mendicantes se unieran y juntaran fuerzas. ${ }^{50}$

\section{Fuentes agustinas}

En relación con las fuentes agustinas, las crónicas de esta orden tratan las misiones del Japón dentro de la martirología y conceden especial atención al

notas), Fernando Blanco, O.P. (transcripción y redacción), Madrid, Secretariado de Misiones Dominicanas, 1993 [primera ed. Manila, 1626].

46. Naohiro Takizawa, "A Study of Ars grammaticae iaponicae linguae (1632) by Diego Collado and its Sources", tesis doctoral, Ann Arbor, Michigan, umi Dissertation Services, 1996.

47. Diego Collado, Niffon no cotóbani yô confesion.../Modus confitendi et examinandi..., Roma, Typis \& impensis Sacr. Congreg. de Propag. Fide, I632.

48. Diego Aduarte, Relatione de molti che hanno patito con titolo di christiani nel Giapone dall'anno I626 fino a quello de I628. \& in particolare di sei di loro della religione di S. Domenico, doi sacerdoti spagnoli, e quattro laici giaponesi, Roma, Stefano Paolini, I632.

49. Diego Aduarte, Historia de la provincia del Santo Rosario de la orden de predicadores en Filipinas, Japón y China, 2 t., Manuel Ferrero, O.P. (introd.), Madrid, Consejo Superior de Investigaciones Científicas-Departamento de Misionología Española, I962, t. I, pp. 4I6 y 526 [primera ed. Manila, I640].

50. Ibidem, t. II, p. 77. Aduarte señala que fray Hernando de San José, vicario provincial de la Orden de N.P.S. Agustín, llevaba ya tres años en Japón, junto con el dominico Alonso Navarrete, vicario provincial de la Orden de Predicadores, a raíz de que había quedado solo en el momento en que sus compañeros salieron desterrados. 
beato mexicano Bartolomé Gutiérrez (I580-1632). En efecto, Basalenque, en su Historia de la provincia de San Nicolás de Tolentino..., saca a colación a fray Bartolomé — formado en el colegio de San Pablo de Yuririapúndaro y martirizado en Japón—, para demostrar la excelencia de dicho colegio agustino, ya que de ahí salió el gran predicador, misionero y mártir en Japón. También es de observar que para hablar de dicho beato, el cronista se basó en una carta y relación que Bartolomé escribió en la cárcel, cuyos originales se conservaban en aquel entonces en el archivo de Valladolid (hoy Morelia). ${ }^{\text {I }}$

José Sicardo, autor de la Christiandad del Japón y dilatada persecvcion que padecio..., ${ }^{52}$ registró las actividades evangélicas agustinas y los procesos de la consolidación de la política de prohibición católica en Japón. A diferencia de otros autores agustinos, Sicardo aborda a los mártires de distintas órdenes, por lo que esta obra se leyó en diferentes ámbitos religiosos. Incluso se registra un ejemplar en el inventario de los libros de la biblioteca del colegio franciscano de San Fernando de México.53

Matías de Escobar, en la Americana Thebaida, ofrece datos sobre los contratiempos que sufrieron los misioneros de su orden para continuar la empresa evangélica durante las persecuciones. Así, al llegar a Japón, los frailes "dejaron sus hábitos y se vistieron, para ocultarse, de los vestidos del país".54 Empero, más tarde fueron capturados y terminaron en martirio.55 A su vez, Agustín María de Castro (I740-I80I), agustino español que llegó a Manila en I759 y ejerció el ministerio apostólico en las islas Filipinas, escribió el Osario venerable..$^{6}$ En este texto, el autor recopiló las referencias de los agustinos destaca-

51. Diego Basalenque, Historia de la provincia de San Nicolás de Tolentino de Michoacán del orden de N.P.S. Agustín, José Bravo Ugarte (introd. y notas), México, Jus, 1963, pp. I3I-I32 [escrito en I644 e impreso en I673].

52. Sicardo, op. cit.

53. Biblioteca Nacional de México, Fondo Reservado, ms. núm. 64II, "Índice de todos los libros, que contiene la librería común del colegio apostólico de San Fernando de México, según el orden con que están colocados, año de I80o”, p. I 58.

54. Matías de Escobar, Americana Thebaida. Vitas Patrum de los religiosos hermitaños de N.P. San Agustín de la Provincia de S. Nicolás Tolentino de Mechoacán, México, Imprenta Victoria, I924, p. 603 [primera ed. I729].

55. Ibidem, pp. 612-616.

56. Agustín María de Castro, Misioneros agustinos en el Extremo Oriente 1565-1780 (Osario venerable), Manuel Merino (ed., introd. y notas), Madrid, Instituto Santo Toribio de Mogrovejo/Consejo Superior de Investigaciones Científicas, 1954 [primera ed. I780]. 
dos en Oriente, entre las cuales incluyó la biografía de Bartolomé Gutiérrez desde su llegada a Japón en I6I2 hasta su martirio en I632.57

La retórica agustina de exaltar la figura del beato referido tuvo continuidad incluso en el siglo xx. En el marco del proyecto de investigación histórica de la orden agustina propuesto por el padre general fray Luciano Rubio, O.S.A., en 1960, Nicolás Navarrete (1905-1973) se encargó de redactar su Historia de la provincia agustiniana de San Nicolás de Tolentino de Michoacán.$^{58}$ En esta obra, el cronista amplió referencias biográficas de fray Bartolomé con base en la nueva documentación. Así, dilucidó las actividades del beato en el Oriente como: "en el convento de Manila moró fray Bartolomé por un sexenio, entrenándose para su futura misión y desempeñando el importante y delicado cargo de maestro de novicios"; 59 y entre sus alumnos estaban "los PP. fray Tomás de San Agustín y fray Miguel de San José, ambos naturales del Japón, ilustres mártires de Jesucristo", 60 con quienes Bartolomé había aprendido las nociones generales de la lengua y la idiosincrasia japonesas. ${ }^{61}$ Esto prueba que Filipinas sirvió de sede de operaciones de sus misiones en Asia también para los agustinos. Asimismo, Navarrete relató la trayectoria misionera de Bartolomé en Japón, ya que éste estuvo principalmente en Omura (Nagasaki) y Usuki (Bungo), aunque llegó hasta Osaka. ${ }^{62}$

La narrativa tradicional del siglo XVI al XVIII se caracterizó por resaltar las contribuciones sociales de los misioneros con el fin de construir una imagen positiva de las instituciones católicas. Además, la tendencia de subrayar la historia de persecuciones y martirios hizo que los cronistas equipararan la historia de la evangelización de Japón con la de la Iglesia primitiva. ${ }^{63}$ Así, al gobernante japonés que actuaba con "malicia" y "cierta enemistad" con los misioneros ${ }^{64}$

57. Ibidem, p. 49.

58. Nicolás Navarrete, Historia de la provincia agustiniana de San Nicolás de Tolentino de Michoacán, 2 vols., México, Porrúa, 200I, vol. I, p. 3 [primera ed. 1978].

59. Ibidem, p. 250.

6o. Idem.

6I. Ibidem, pp. 250-25I.

62. Ibidem, p. 254

63. Aduarte, Historia de la provincia del Santo Rosario..., op. cit., t. II, p. 9: "No fuera la nobilísima Iglesia del Japón tan ilustre, ni con tanta razón estimada, si no se hubiera parecido tanto a la primitiva, fundada por el Señor y congregada por sus santos Apóstoles, la cual, desde su principio, tuvo persecuciones".

64. Ibidem, t. II, p. 55 . 
se le asoció con Nerón y Diocleciano. ${ }^{65}$ Esta manera de interpretar la historia de las misiones conforme a los valores cristianos, calificando a los políticos anticristianos de "malos" y a los integrantes de la Iglesia de "buenos", repercutiría hasta en la historiografía de la centuria pasada. Así, no sólo los autores jesuitas como Laures, sino también los historiadores seculares como Okamoto, consideraron la presencia de la Iglesia en Japón como una sociedad "utópica" y "libre", mientras que el fracaso de la dominación católica en ese país se veía como "tragedia". ${ }^{66}$ No obstante, Navarrete ofreció una visión distinta sobre los gobernadores japoneses que llevaron a cabo las persecuciones de los cristianos. Así, afirmó que Gonrocu, gobernador de Nagasaki, fue "hombre de sentimientos humanitarios" que se veía obligado a obrar contra su propia voluntad. Dicho gobernador había ayudado, según el mismo cronista, a que Bartolomé Gutiérrez sobreviviera a las persecuciones varios años:

Con cierta habilidad política, [Gonroku] tenía en su gabinete uno o más católicos laicos, por cuyo conducto se comunicaba con los misioneros para avisarles cuándo habían de tomar mayores precauciones. Así se explica humanamente, sin prescindir de la ayuda divina ni de su gran agilidad personal, que Fray Bartolomé haya sido el único misionero que pudo escabullirse de la acción policiaca por un lapso de doce ańos. ${ }^{67}$

\section{Fuentes occidentales civiles}

Entre las fuentes producidas en el ámbito civil, cabe citar, primeramente, el trabajo de Scipione Amati, quien presenció la misión diplomática de Hasekura Tsunenaga en Roma y escribió Historia del regno di Voxv del Giappone, dell'antichita, nobilta, e valore del svo re Idate Masamvne... En esta obra, el cronista registró no sólo la entrevista de dicho embajador con el sumo pontífice, sino también explicó la relación amistosa entre Sotelo y Date Masamune (I567-1636), lo que hizo que este daimyō de Sendai enviara una delegación a la Nueva España y Europa. ${ }^{68}$ También hay que señalar un retrato de Hase-

65. Escobar, op. cit., pp. 600 y 609.

66. Johannes Laures, The Catholic Church in Japan, Rutland, Tokio, Charles E. Tuttle Company, I954, p. V; Yoshitomo Okamoto, Namban bijutsu [1967], Tokio, Heibonsha, I968, p. 27.

67. Navarrete, op. cit., p. 255.

68. Scipione Amati, Historia del regno di Voxv del Giappone, dell'antichita, nobilta, e valore 
I. Retrato de Hasekura Tsunenaga, tomado de Amati, Historia del regno di Voxv del Giappone, dell'antichita, nobilta, e valore del svo re Idate Masamvne..., op. cit. (vid. n. 68), s.p. Fondo Reservado, Biblioteca Nacional, UnAM.

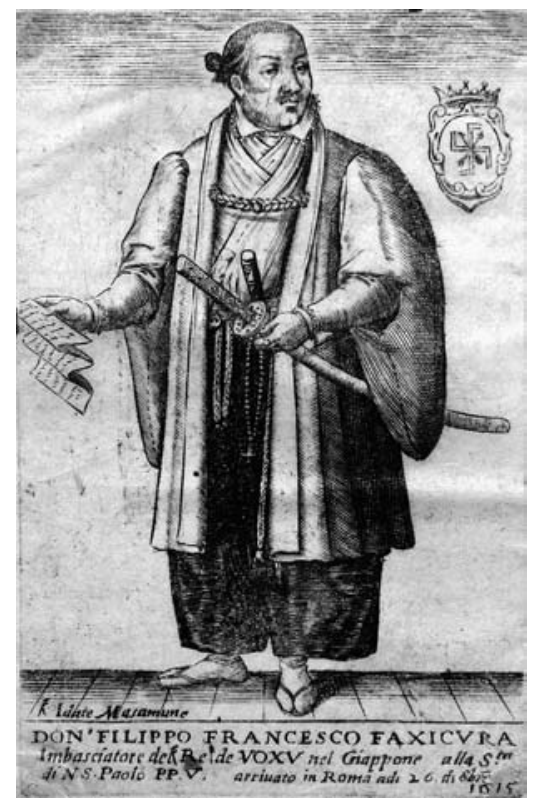

kura insertado en el citado texto, donde aparece vestido con una camisa europea abajo del kimono (fig. I).

Entre los escritos de los funcionarios virreinales, merecen citarse las Relaciones del Japón (I609) de Rodrigo de Vivero (I564-I636), gobernador interino de Filipinas que naufragó y arribó a Japón en su viaje de regreso a la Nueva España en 1608. En sus Relaciones describió no sólo las ciudades y las costumbres japonesas, sino también las entrevistas que tuvo con las autoridades locales con la ayuda de Sotelo. ${ }^{69}$ De igual modo, Sucesos de las islas filipinas (I609) de Antonio de Morga (I559-I636), ${ }^{\circ}$ alcalde del Crimen de la Real Audiencia de la Nueva España, es una obra de importancia, ya que además de los datos administrativo-comerciales y las descripciones culturales de Filipinas, el

del svo re Idate Masamvne, delli favori, c'ha fatti alla Christanità, e desiderio che tiene d'esser Christiano, e dell'aumento di nostra santa Sede in quelle parti, Roma, Giacomo Mascardi, I6I5. 69. Rodrigo de Vivero, "Relación del Japón”, Manuel Romero de Terreros (introd. y notas), Anales del Museo Nacional de Arqueología, Historia y Etnografía, I934, t. I, pp. 74-I I I [primera ed. I609].

70. Antonio de Morga, Sucesos de las islas filipinas, México, Casa de Geronymo Balli, I609. 
autor abordó asuntos relativos a los países periféricos, incluso las persecuciones y los martirios en Japón.

Con respecto a la rebelión Shimabara (I637-I638), un levantamiento armado de campesinos kirishitan en la península Shimabara, en Nagasaki, hay dos manuscritos atribuidos a los civiles. El primero es una carta que Nicolaes Couckebacker — jefe de la oficina de comercios exteriores de Dejima en Nagasaki entre I633 y I639- escribió al general Antonio van Diemen en Batavia. ${ }^{\text {II }}$ El segundo es de Duarte Corrêa (m. I639), natural de Alemquer, Portugal, y familiar de Santo Oficio, que estuvo preso en la cárcel de Omura, en Nagasaki, durante la revuelta referida y terminó siendo mártir en I639. Este autor recopiló noticias desde la prisión acerca del levantamiento y escribió una Relaçam do alevantamento de Ximabàra, dirigida a Antonio Francisco Cardim, S.J., en Macao, la cual se publicó en Lisboa en I643. ${ }^{72}$

Asimismo, la opresión de los misioneros y los fieles japoneses llegó a ser tratada en obras literarias. Lope de Vega, con base en los escritos de Jacinto Orfanell,73 narró de manera lírica la heroicidad del acto de muerte en su Triunfo de la Fee en los reynos del Iapon por los años de I6I4 y I6I5. ${ }^{74}$ Por otra parte, Montanus (I625-I683), en su Atlas Japannensis (Ámsterdam, I669), dio a conocer por primera vez las prácticas del fumi-e $e^{75}$ de los holandeses en aquella tierra. Del mismo modo, insertó un grabado con las torturas aplicadas a los kirishitan en Unzen, Nagasaki, además de presentar noticias sobre Cristóvão Ferreira (ca. I580-1650), ex jesuita que renunció a su fe, tomó el nombre japonés Sawano Chūan y colaboró en las persecuciones. ${ }^{76}$ La actitud de

7I. Nicolaes Couckebacker, carta del Io de enero de I638 dirigida al general Antonio van Diemen. Este manuscrito se conserva en el Archivo Nacional de La Haya, en Holanda. Fue publicado en Nagasaki kenshi Shiryō hen III, Nagasaki Kenshi Hensan Iinkai (ed.), Tokio, Yoshikawa Kōbunkan, 1966.

72. Duarte Corrêa, Relaçam do alevantamento de Ximabàra (I638), Alemquer, Typ. E Pap. H. Campeao, I90 [ [primera ed. I643]; Nagasaki kenshi Shiryō hen III, op. cit., pp. 223-232.

73. Charles Ralph Boxer y J.S. Cummins, "The Domenican Mission in Japan (I602-I622) and Lope de Vega", en Archivum Fratrum Praedicatorum, vol. XXXIII, 1963, p. 37.

74. Lope de Vega, Triunfo de la Fee en los reynos del Iapon por los años de I6I4 y I6I5, Madrid, impreso por la viuda de Alonso Martín de Balboa, I6I8.

75. Fumi-e "pisar imágenes" fue una práctica instituida por el Bugyōsho (comisaría ejecutiva) de Nagasaki para detectar a los kirishitan ocultos en la época de persecución. Los acusados tenían que demostrar el desconocimiento de la fe pisando las imágenes católicas enfrente de la autoridad civil.

76. Arnoldus Montanus, Atlas Japannensis: Being Remarkable Addresses by Way of Embassy from the East-India Company of the United Provinces, to the Emperor of Japan, John Ogil- 
los holandeses de profanar las imágenes sagradas causó polémica dentro de la sociedad europea, por lo que Swift (I667-I745) hizo una sátira de este hecho en su Gulliver's Travels, enviando al protagonista a Nagasaki en $1709 .{ }^{77}$

Germain Felix Meijlan (I785-I83I), de la Compañía Holandesa de las Indias Orientales, aprovechó su estancia en Dejima entre I827 y I830 para escribir sobre los sistemas político-administrativos, las costumbres, las artes e industrias de Japón, en especial de Nagasaki. En su Japan, ${ }^{78}$ registró las prácticas de fumi-e, así como una tradición oral acerca de Hagiwara Yūsa, quien produjo 20 fumi-e de latón en 1669 por encargo del Bugyōsho (comisaría ejecutiva) de Nagasaki. Es decir, cuando se inició la ceremonia de fumi-e, los funcionarios japoneses no tenían más que una tabla de cobre. Ante la necesidad de realizar esta práctica en varios sitios para aniquilar a los kirishitan, se mandó a Yūsa reproducir las imágenes sagradas. Sus trabajos salieron tan excelentes que no se distinguían de las obras originales. Sin embargo, el premio que recibió este artífice por elaborar dichas piezas fue ser degollado por orden del shögun para prevenir que Yūsa trabajara con posterioridad para los kirishitan. ${ }^{79}$

by (trad.), Londres, Johnson, I670 [primera ed. Ámsterdam, I669]. Con respecto a Sawano Chūan (沢野忠庵), este personaje se convirtió en modelo en la novela histórica de Shūsaku Endo, titulada Chinmoku (沈黙, Silencio, 1966).

77. Jonathan Swift, Gulliver's Travels, Peter Dixon y John Chalker (eds.), Harmondsworth, Penguin Books, 1985, $3^{\text {a }}$ parte, cap. XI, p. 263 [primera ed. 1726]: "Before we took shipping, I was often asked by some of the crew, whether I had performed the ceremony above mentioned? I evaded the question by general answers, that I had satisfied the Emperor and court in all particulars. However, a malicious rogue of a skipper went to an officer, and pointing to me, told him, I had not yet trampled on the crucifix; but the other, who had received instructions to let me pass, gave the rascal twenty strokes on the shoulders with a bamboo, after which I was no more troubled with such questions". ("Antes de embarcar me preguntaron muchas veces algunos de los tripulantes si había cumplido la ceremonia a que ya he hecho referencia. Evadí la respuesta diciendo en términos vagos que había satisfecho al emperador y a la corte en todo lo preciso. Sin embargo, un bribonazo paje de escoba se acercó a un oficial y, apuntándome con el dedo, díjole que yo no había aún hollado el crucifijo; pero el otro, ya advertido para dejarme pasar, dio al tunante veinte latigazos en las espaldas con un bambú; después de lo cual no volvió a molestarme nadie con tales preguntas", fragmento tomado de Jonathan Swift, Los viajes de Gulliver, cervantesvirtual.com —edición digital basada en la edición de Buenos Aires, Espasa-Calpe, 1943 (Javier Bueno, trad.)—, p. 403; Yakichi Kataoka, Fumie. Kinkyō no rekishi, Tokio, Nippon Hōsō Shuppan Kyōkai, I975, p. Io.

78. Germain Felix Meijlan, Japan: voorgesteld in schetsen over de zeden en gebruiken van dat ryk, byzonder over de ingezetenen der stad Nagasaky, Ámsterdam, M. Westerman, I830.

79. Germain Felix Meijlan, Japan, traducido en Nagasaki kenshi Shiryō hen III, op. cit., pp. 394-395. 


\section{Registro de la Sociedad por las Misiones Extranjeras de París}

Al finalizar el periodo Edo, tras haber transcurrido 200 años de aislamiento político-económico y de persecuciones cristianas, Japón se vio obligado a reabrir el país bajo la presión de las potencias occidentales e incluso a permitir el restablecimiento de las instituciones eclesiásticas en las áreas residenciales de los extranjeros. ${ }^{80}$ Bernard-Thadée Petitjean (I829-I884), de la Sociedad por las Misiones Extranjeras de París, primer obispo de la catedral de Oura, en Nagasaki, relató, en una carta fechada el i8 de marzo de I865, el "descubrimiento"8r de los descendientes kirishitan, ya que éstos habían ido a confesar ante el obispo francés. ${ }^{82}$ De esta forma, la noticia de la pervivencia de la fe católica se difundió por diferentes partes del mundo. La principal aportación de Petitjean fue dar a conocer ampliamente las oraciones y el libro sagrado de Tenchi hajimari no koto (Comienzo del cielo y la Tierra), ${ }^{83}$ transmitidos entre el círculo de los kirishitan ocultos. Además, con base en estas fuentes analizó los conocimientos religiosos de dichos kirishitan para explorar la posibilidad de reutilizar este saber cristiano local en la reevangelización de Japón.

Respecto al Comienzo del cielo y la Tierra, este título proviene de las palabras con que se inicia el texto y alude al Génesis. El manuscrito consta de I5 capítulos y presenta cierto desorden cronológico y estructural, así como con-

80. La labor evangélica de la Sociedad por las Misiones Extranjeras de París (MEP) en Japón, como expongo en el texto, estuvo relacionada con los cambios que se dieron antes de finalizar el periodo Edo. Es decir, las potencias occidentales comenzaron a presionar a Japón para que anulara la política de aislamiento político-económico, reabriera el país y firmara el tratado de comercio. Frente a esta circunstancia emergente, la MEP se preparó para la reevangelización en Japón desde I838. Así, el padre Théodore-Augustin Forcade entró en Ryukyu (actual Okinawa) en I844 con la intención de ingresar al territorio principal del Japón. En I858, el shogunato Tokugawa concertó un tratado de comercio con cinco países: Estados Unidos, Gran Bretaña, Holanda, Rusia y Francia, además de permitir la fundación de iglesias en las zonas residenciales de extranjeros. A raíz de esto, al año siguiente Prudence-SéraphinBarthélemy Girard arribó a Yokohama, mientras que Louis-Théodore Furet se estableció en Nagasaki en 1863 e hizo el proyecto de la catedral de Oura. Esta nueva sede episcopal fue concluida por Petitjean a finales de I864.

8I. Aquí es importante notar que la referencia de Petitjean "descubrimiento" está basada en el criterio europeo, ya que para los kirishitan de Japón, este hecho no significó un "descubrimiento", sino un reencuentro con la institución católica.

82. Bernard-Thadée Petitjean, Petitjean shikyō shokan shū, Nagasaki Chihō Bunkashi Kenkyūjo (ed.), Nagasaki, Nagasaki Junshin Joshi Tanki Daigaku, I986, pp. 68-72.

83. Este texto aparece indicado "Tendjino Hadhimari no koto" en la carta de Petitjean. 
fusiones conceptuales al mostrar las narraciones del Antiguo y el Nuevo Testamento. Además, incluye anécdotas que no existen en la Biblia. Se le ha considerado una fuente que muestra la transición doctrinal del catolicismo al culto local y ha cobrado especial importancia en el estudio de la religión y la etnología.

\section{Fuentes primarias japonesas}

Aparte del citado texto sagrado de los kirishitan ocultos, hay otras fuentes japonesas de gran peso. Primeramente, cabe citar el género de documentos denominado hoy "literatura kirishitan". Se trata de obras religiosas escritas por los conversos japoneses. ${ }^{84}$ Los autores más destacados son Paulo Yōhō-ken (養 方軒パウロ, I5IO-I596), quien redactó los guiones para las representaciones teatrales de la Pasión de Cristo y de la Navidad; su hijo Vicente Hōin (法印ヴ イセンテ, n. I538), quien tradujo gran parte de los textos de prácticas cristianas junto con su padre; 85 Gracia Hosokawa (細川ガラシヤ, I563-1600), que dejó una serie de cartas dirigidas a Gregorio de Céspedes, S.J., así como una cantidad considerable de poemas de fe, ${ }^{86}$ y Fabian Fucan (不干斎ハビアン, n. 1565), quien abordó las cuestiones teológico-filosóficas e hizo una refutación del confucionismo, el shintoismo y el budismo en sus obras de Myötei Mondō (妙貞問答, Diálogo entre Myoshu y Yutei, 1605). ${ }^{87}$

Como otras fuentes producidas en el ámbito católico de Japón, cabe señalar los Kirishitan-ban, impresos de la Compañía de Jesús realizados a finales del siglo XVI y principios del XVII (fig. 2). Los textos para los misioneros están escritos en letras latinas, mientras que las obras dirigidas a los japoneses vie-

84. John England, "Asian Christian Writers in the $16^{\text {th }}-\mathrm{I} 8^{\text {th }}$ Centuries", Inter-Religio, núm. 34, invierno de 1998, p. 70, http://www.nanzan-u.ac.jp/shubunken/publications/ miscPublications/I-R/pdf/34-England.pdf (consultado el 28 de junio de 2008).

85. Johannes Laures, Kirishitan Bunko: A Manual of Books and Documents on the Early Christian Mission in Japan, Tokio, Universidad Sofía, 1957, p. 40; Arimichi Ebisawa, Toyo Bunko, núm. I4, 1964, pp. 9-67; Joseph Francis Moran, The Japanese and the Jesuits: Alessandro Valignano in Sixteenth-century Japan, Londres/Nueva York, Routledge, 1993, p. I85.

86. Geoffrey C. Gunn, First Globalization: The Eurasian Exchange, I500 to I80o, Lanham, Maryland, Rowman \& Littlefield, 2003, p. 90.

87. Eisho Nasu, “Fucan Fabian's Critique of the Ikko-shu: A Christian Intellectual's View of Jodo Shinshu at the Dawn of the Tokugawa Period (Proceedings [2] of the Fifty-fifth Congress held at Komazawa University)", Journal of Indian and Buddhist Studies, vol. 53, núm. 2, marzo de 2005, pp. 772-767. http://ci.nii.ac.jp/naid/I10002707444/ 
nen en kanji (caracteres chinos) y kana (silabarios japoneses). En la actualidad, se identifican 32 libros de este tipo, entre los que se incluyen textos de carácter religioso como la Dochirina kirishitan (Doctrina cristiana) y Sarube Regiina (Salve Regina), así como la literatura japonesa clásica como Heike monogatari (El cuento del Heike). Estas producciones son de gran importancia para la historia de la imprenta en Japón, además de ser valiosas fuentes para estudios religiosos, culturales y lingüísticos. Para la historia del arte, las ilustraciones que contienen estos textos como emblemas jesuíticos sirvieron de fuente gráfica para otras produciones visuales.

Por otra parte, los textos sobre los kirishitan escritos por los japoneses no conversos fueron al principio registros de costumbres que ellos consideraban raras. No obstante, en el periodo de persecución surgió un género literario que criticaba al cristianismo desde la perspectiva budista. Las obras más destacadas dentro de éste fueron Ha-Deus (破堤宇子, Deus refutado, I620) de Fabian Fucan; Köfukuji hikki (興福寺筆記, Manuscrito del templo Kōfuku, 1647) y Taijijashitsuron (対治邪執論, La teoría de exterminación del mal, I648) del monje de la secta zen Sessō Sōsai (雪空宗崔, I589-I649); Ha Kirishitan (破吉 利支丹, Kirishitan refutados, I662) del monje de la secta Sōtō Suzuki Shōsan (鈴木正三, I579-1655), y la obra anónima Kirishitan Monogatari (吉利支丹 物語, Cuentos de los kirishitan, I639). ${ }^{88}$ Cabe señalar que algunas de las obras anticristianas se ilustraron con grabados de madera para mostrar la exterminación de los misioneros y sus creyentes.

Asimismo, existen varios ensayos de carácter histórico escritos por los mismos conversos japoneses del siglo xvi al xviII: Gamo Ujitsato-ki (I595), Hosokawa Tadoki (I563-I600), Itasaka Bokusai (I578-I655), Matsudaira Nobutsuna (I596-I662), Kumkuzawa Banzan (I6I9-I69I), Bai Buntei (I633I72I), así como el confucionista Hakuseki Arai (I652-I725). De estas obras se destaca el Seiyō kibun (西洋紀聞, Asuntos informados sobre el Occidente, 1709) del último autor. ${ }^{89}$ Arai era una figura excepcional de la época. Pese a que el shogunato Tokugawa aplicaba la política de aislamiento, tenía amplio conocimiento sobre el mundo exterior. Como historiador, su metodología y

88. Kōichi Shimizu, "Kirishitan kenkyü", en Hubert Cieslik, S.J. (coord.), Nihonshi shōhyakka. Kirishitan, Tokio, Tokyodō, 1999, pp. 8-15; George Elison, Deus Destroyed: The Image of Christianity in Early Modern Japan, Cambridge, Massachusetts, Harvard University Press, 1973.

89. Hakuseki Arai, "Seiyō kibun”, en Akira Matsumura (ed. y notas), Arai Hakuseki, Tokio, Iwanami Shoten, 1975, pp. 7-82. 
2. Gvia do pecador ぎやどペかどる, Nagasaki, I599. Tomada de Kirishitanbanshu I, Tokio, Yagi Shoten (Tendri Toshokan Zenpon Sosho, 38), 1976, p. 68. Colección de la Biblioteca Central de Tenri, Universidad de Tenri.

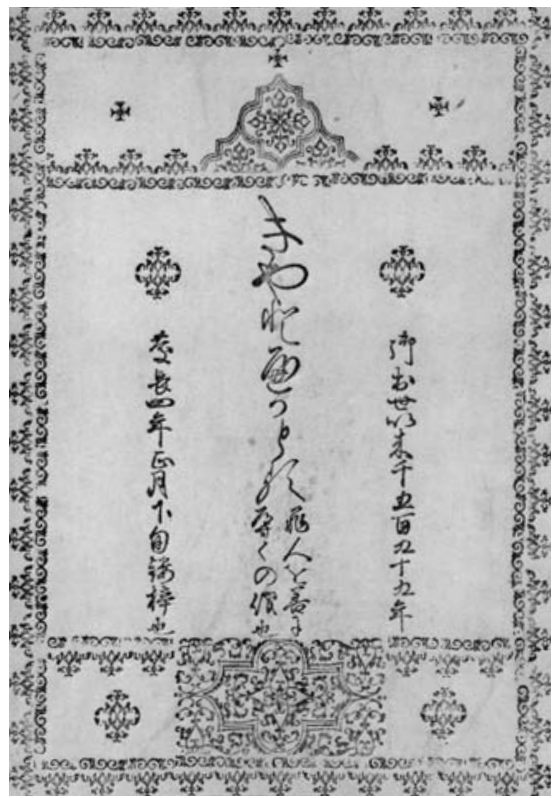

su visión se caracterizaron por el radicalismo, ya que rompió con la concepción histórica tradicional basada en la mitología y el esoterismo. Para obtener interpretaciones lo más objetivas posibles, empleó un método comparativo y concedió importancia a los aparatos críticos, en especial, a las fuentes documentales. Además, concibió la historia no como acumulación cronológica de sucesos, sino como unidad o secuencia sucesiva de procesos que conducen a transformaciones y desarrollos.

La metodología de Arai fue en gran medida influida por su relación con los holandeses, ${ }^{\circ \circ}$ así como con Giovanni Battista Sidotti, S.J. (I678-1715), quien arribó de manera ilegal a Yakushima, isla situada en el suroeste del Japón, en agosto de 1708. Debido a la prohibición del cristianismo, Sidotti fue detenido y trasladado primero a Nagasaki y después a Edo, donde Arai, quien tenía un cargo político, entrevistó e interrogó al jesuita en cuatro ocasiones durante los últimos dos meses de 1709.9 ${ }^{91}$ El Seiyō kibun, texto del confucionista referido,

90. Takeo Kuwabara, “Arai Hakuseki no senkusei”, en Takeo Kuwabara (ed.), Arai Hakuseki shü, Tokio, Chikuma Shobō, I970, pp. 8-I2.

91. Shūichi Katō, "Arai Hakuseki no sekai", en Arai, op. cit., p. 507. 
fue fruto de este encuentro. Ahí, Arai registró las conversaciones que había tenido con Sidotti acerca de los motivos de su llegada al Japón, así como información sobre la autoridad católica en Europa, la historia de la misión católica y su prohibición en Japón, una síntesis de las Sagradas Escrituras y aspectos de geografía y política relatados por el mismo jesuita.

Asimismo, para tratar el catolicismo, Arai se basó en las ideas de Matteo Ricci, S.J. (I552-I6ro), cuyo libro, donde abogaba por el empleo del concepto confuciano de Tenshu (天主, "dueño del cielo", Tianzhu en chino) en lugar de Deus, había sido prohibido en Japón en 1630.92 Arai se apoyó también en el Sho Sansatsu (書三冊, Textos de tres tomos), escrito por el ex jesuita siciliano Giuseppe Chiara (I602-I685).93 Este autor llegó originalmente a Chikuzen (actual prefectura de Fukuoka) como misionero clandestino en mayo de I643, pero fue detenido y enviado a Edo donde fue encarcelado en el Kirishitan yashiki, "mansión de los kirishitan", que servía de calabozo para castigar a los misioneros y a los conversos japoneses; después de renunciar a la fe católica, se nacionalizó japonés y tomó el nombre nativo Okamoto San'uemon. ${ }^{94}$

En el periodo de persecución, las autoridades civiles japonesas elaboraron una serie de documentos para exterminar a los kirishitan. Al respecto, cabe mencionar los testimonios de kirishitan korobi, "cristianos caídos", que tratan de las cartas de renuncia de fe, elaboradas al ser descubiertas sus creencias y prácticas religiosas prohibidas. Para el estudio de la cultura material, la importancia de estas fuentes radica en que incluyen referencias acerca de los "instrumentos kirishitan", objetos devocionales y litúrgicos confiscados, como imágenes, medallas, rosarios y cruces. ${ }^{95}$ Con relación a esto, también es de advertir que junto con el inventario de los objetos devocionales encontrados se indican de vez en cuando los sitios donde se hallaron dichas hechuras en planos arquitectónicos sencillos. ${ }^{96}$

92. Matsumura, notas del texto de Arai, op. cit., p. 62.

93. Ibidem, p. Iо.

94. Ibidem, p. 30.

95. Biblioteca de la Universidad de Kumamoto, Matsui bunko, doc. núm. 54, "Shūmon aratame bunsho", microfilme 55(3)20; Biblioteca de la Universidad de Kumamoto, Matsui bunko, doc. núm. 53, "Shimoge-gun bateren monto gokaichō", microfilme 84(3)ı8, f. I6; Kyoko Kawaguchi, "Kirishitan korobi shōmon. Kukamoto Daigaku fuzoku toshokan-zō", Kumamoto Shigaku, núm. 19-20, diciembre de 1960, pp. 59-66.

96. Mario Marega, Bungo Kristan shiryo. Documents Concerning the Persecution of the Christians of Bungo, Kyushu, Beppu, Salesio-kai, 1942, pp. 76-77; Zoku Bungo Kristan shiryo. Do- 
Asimismo, se elaboraron libros manuscritos que registran nombres, domicilios, profesiones, fechas de nacimiento y muerte de los ex kirishitan y sus parentescos con el fin de vigilarlos. ${ }^{97}$ Así, los funcionarios que se encargaron de despachar los asuntos de los kirishitan obtuvieron numerosos datos de importancia. Masashige Inoue (井上政重, I585-I66I), quien estuvo a cargo de Ometsuke (大目付, nombre del puesto de vigilancia del shogunato Tokugawa) entre i632 y I658, compiló y dejó a su sucesor un corpus documental con el fin de que los antecedentes sirvieran de guía para tomar medidas con respecto a los kirishitan. Inoue fue kirishitan antes del decreto de prohibición, lo cual implica que los ex creyentes que conocían muy bien los asuntos del círculo kirishitan contribuyeron como líderes de las persecuciones.

Por otra parte, en el siglo XVII surgió la tendencia de aproximarse al fenómeno kirishitan desde una perspectiva científica. Tokugawa Mitsukuni (徳 川光图, I628-I70I), daimyō de Mito y representante de la escuela de estudio histórico Mitogaku (水戸学), emprendió la labor de compilar la monumental obra Dai Nihon shi (大日本史, Historia del gran Japón, 397 rollos en 226 volúmenes y 5 rollos de índice). Este trabajo continuó aún después de la muerte de Mitsukuni, ya que en I799 el confucionista Tachihara Suiken (I744-I823) realizó correcciones al texto con el fin de publicarlo para la conmemoración centenaria de la muerte de dicho daimyo. Lo destacable de Mitsukuni es que, pese a la prohibición cristiana - con el propósito de compilar un compendio histórico-, solicitó clandestinamente a los señores de cada feudo que le proporcionasen documentos, dibujos y artículos relacionados con los kirishitan, como relicarios, medallas, rosarios y disciplinas. Así, conformó un acervo, aunque prohibió el acceso al mismo. Empero, una centuria después, por orden del clan Mito, Tachihara Suiken asumió el encargo de inventariar dicha colección. La cantidad de documentos y objetos fue tal que sólo se limitó a registrar una parte mínima en su Kirishitan hōfuku shokibutsu mokuroku (吉利支丹法服諸 器物目録, El inventario de la indumentaria y artículos kirishitan, 1800$) .9^{98}$

Asimismo, en el ámbito del clan Date, aprovechando que se debían ventilar los objetos guardados en la bodega — los artículos kirishitan-, el vasa-

cuments Concerning the Persecution of the Christians of Bungo, Kyushu, Tokio, Don Boscosha, 1946, pp. 91 y 109.

97. Kumamoto Prefectural Library, Kensei Shiryo (documentos de la política prefectural), del núm. 48-I al 48-38.

98. "Mitoke denrai no kirisutokyō shorui", Toshokan Zasshi, núm. 52, I3 de marzo de 1937, p. 46. 
llo Takano Munekane (高野統兼) registró los objetos traídos por Hasekura Tsunenaga el 23 de julio de 1774 en el libro Takano ke kiroku (高野家記録, Registros de la familia Takano). Más tarde, Ōtsuki Gentaku (大槻玄沢, I757I827), confucionista del feudo Sendai, realizó un inventario, estudio y dibujos del mismo acervo siguiendo la orden del clan Date. El fruto de este trabajo fue Kinjōhiun (金城秘韞, Los secretos del castillo fortificado de oro, I8I 2) (fig. 3), cuyo título está traducido libremente al inglés como "Document of Articles of Hasekura Tsunenaga”.99 Por otro lado, Ōta Zensai (太田全齋, I799-I829), confucionista y estudioso de las letras chinas del dominio Fukuyama (Fukuyama-han), en la actual prefectura de Hiroshima, realizó una interpretación de los textos utilizados por los kirishitan como libros de oración en Kirisutoki (契利欺督記, $c a$. I789-1800). ${ }^{100}$

\section{Albores de los estudios kirishitan}

En el contexto japonés, la aproximación al fenómeno kirishitan con una perspectiva científica tuvo sus antecedentes en el periodo Edo entre los confucionistas y estudiosos de rangaku, "ciencias de Holanda". Después de la reapertura del archipiélago al mundo occidental en la década de i850, la sociedad japonesa sufrió una serie de cambios radicales: la transformación del régimen político del feudalismo militar al imperialismo constitucional y la introducción de nuevas ciencias, cultura y sistema educativo occidentales bajo la restauración del periodo Meiji (I868-I9I I). Con todo, este impulso político no supuso una rápida occidentalización, ya que se requirió tiempo para que la ideología occidental penetrara y fuera comprendida por los japoneses. Asimismo, los que comenzaron a abordar las misiones de Japón desde la perspectiva de historia e historia del arte fueron los autores occidentales.

Entre las primeras monografías históricas, lingüísticas y religiosas sobre dicho tema cabe destacar la Histoire de la religion chrétienne au Japon (1869-

99. Sekai to Nihon - Tensho Keicho no shisetsu - The World and Japan - Tensho and Keicho Missions to Europe $16^{\text {th }}$-I th Centuries, Sendai City Museum (catálogo de la exposición), I995, pp. I05 y I60. Kinjōhiun pertenece al acervo de la Biblioteca de la Universidad de Waseda: http://archive.wul.waseda.ac.jp/kosho/bunkoo8/bunkoo8_a0o24/bunkoo8_aoo24.html (consultado el I7 de octubre de 20I0).

ıoo. Izuru Shinmura, Shinmura Izuru senshū, Kioto/Tokio, Kōchō Shorin, I943, vol. I, p. 365 . 


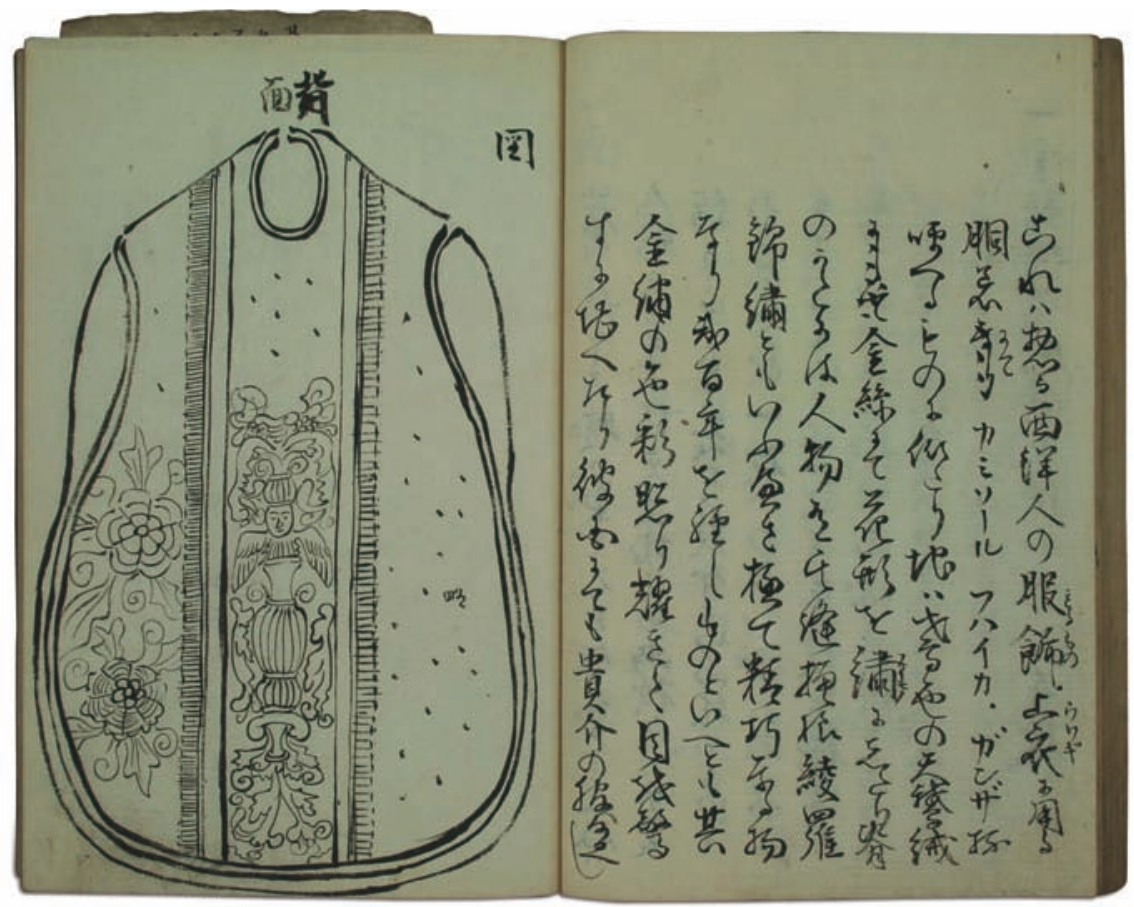

3. Ōtsuki Gentaku, Kinjōhiun, tinta sobre papel, I8I2. Imagen tomada de http://archive. wul.waseda.ac.jp/kosho/bunkoo8/bunkoo8_aoo24/bunkoo8_a0o24.html, núm. 35, consultada el 26 de junio de 2008. Acervo de la Biblioteca de la Universidad de Waseda.

I870) de Léon Pagès, ${ }^{\text {IOI }}$ así como los trabajos de los diplomáticos ingleses y miembros de la Asiatic Society of Japan William George Aston (I84I-I9I I) ${ }^{\text {IO2 }}$ y Ernest Mason Satow (I843-1929). ${ }^{103}$ Joseph Marie Cros, S.J., por su parte,

IOI. Léon Pagès, Histoire de la religion chrétienne au Japon. Depuis I598 jusqu'à I65I. Comprenant les faits relatifs aux deux cent cinq martyrs beatifies le 7 juillet I867, 2 vols., París, Charles Douniol, I869-I870.

I02. William George Aston, "Observations upon the Causes Which Led to the Downfall of the Christian Mission in Japan”, en George A. Sioris (introd.), Early Japanology. Aston, Satow, Chamberlain, Westport, Greenwood Press, 1998, vol. I, pp. 465-486 [primera ed. 1878].

I03. Ernest Mason Satow, "Vicissitudes of the Church at Yamaguchi from I550 to I586" (ponencia presentada el 27 de noviembre de I878), en ibidem, vol. I, pp. 589-620; "The Origin of Spanish and Portuguese Rivalry in Japan" (ponencia presentada el I2 de marzo de I890), en ibidem, vol. II, pp. 335-36r. 
contribuyó al rescate documental jesuítico, ya que logró localizar la Historia do Japão de Luís Fróis, hasta entonces inédita, en la colección Jesuitas na Asia de la Biblioteca Ajuda, en Lisboa, entre diciembre de I894 y enero de I895. Además, abrió una línea de investigación biográfica de los jesuitas destacados, como lo muestra su obra Saint François de Xavier. Sa vie et ses lettres (Tolosa, 1900). ${ }^{\text {I04 }}$

En el área de la historia del arte, Ernest Francisco Fenollosa (I853-1908), profesor norteamericano de filosofía y estética de la Universidad Imperial de Tokio y gran defensor de las tradiciones artísticas japonesas, ${ }^{105}$ fue el primero en interesarse por investigar la influencia occidental en el arte japonés. En su Epochs of Chinese \& Japanese Art, supuso una posible influencia de las copias o interpretaciones de las pinturas religiosas venecianas en la riqueza cromática de las obras de Kanō Eitoku (I543-1590), pintor protegido por Nobunaga y Hideyoshi. Así, cuestionó incluso el grado en que Eitoku pudo haber sido influido por las pinturas al óleo importadas por los kirishitan daimyō. Al respecto, opinó que no se observaba intento alguno de plasmar sombras en sus obras y que dicho pintor pudo haberse inspirado en las pinturas "seudovenecianas" de la Sagrada familia o los retratos de los papas para realizar sus murales de gran fuerza cromática. ${ }^{106}$ Esta hipótesis de Fenollosa no tuvo seguidores. Sin embargo, la línea de investigación iniciada por él tuvo continuidad a lo largo del siglo Xx. ${ }^{107}$ Incluso Tei Nishimura, Yoshitomo Okamoto y Gauvin

I04. Georg Schurhammer, "Nihon-shi to chosha Luís Fróis", en Luís Fróis, Nihon-shi I. Kirishitan denrai no koro, Yanagiya Takeo (trad.), Tokio, Heibonsha, 1973, p. 27.

I05. Fenollosa puso en duda las aproximaciones que se habían hecho hasta entonces al arte japonés. Criticó severamente a William Anderson (I842-1900), quien había valorado sólo las obras del arte oriental que le parecían "realistas", como las obras de Maruyama Ōkio (I733I795) y Katsushika Hokusai (I760-I849), descalificando la mayoría de las hechuras como "distorsiones". Ante esta postura, Fenollosa intentó reconocer el valor creativo y las cualidades estéticas del arte japonés de cada época. Influido por el pensamiento hegeliano, sostuvo la existencia de un "espíritu de la época", así como la unidad estilística de un periodo, por lo que fue el primero en encasillar el arte japonés dentro del concepto esquematizado de los estilos histórico-cronológicos.

106. Ernest Francisco Fenollosa, Epochs of Chinese \& Japanese Art. An Outline History of East Asiatic Design, 2 vols., Nueva York, Dover, I963, vol. II, p. I06 [primera ed. I9I2].

I07. Cfr. Izuru Shinmura, "Seiyō-ga denrai no kigen", Taiyō, enero de I9I7, reimpreso en Izuru Shinmura senshü, op. cit., vol. I, pp. 672-685; "L'introduction de la peinture occidentale au Japon", Revue des Arts Asiatiques, núm. 4, I927, pp. I95-201; Terukazu Akiyama, "First Epoch of European Style Painting in Japan", Bulletin of Eastern Art, núm. I8, I94I, pp. 3-27; Tamon, op. cit.; García Gutiérrez, op. cit. 
Alexander Bailey señalarían más tarde la influencia de las soluciones plásticas de claroscuro y perspectiva lineal en las obras de otros pintores de la escuela de Kanō.

En el ámbito académico japonés, los estudios sobre la historia del periodo Namban surgieron en la última década de la era Meiji, cuando los historiadores comenzaron a realizar un rescate documental en los archivos europeos. Naojirō Murakami (I868-1966) fue pionero en ese campo. Durante su estancia en Europa - de 1900 a 1902-, recopiló las fuentes de primera importancia para las relaciones diplomáticas y misioneras entre Japón y Occidente. Más tarde tradujo al japonés las Cartas que os padres e irmãos da Companhia de Iesus. ${ }^{108}$ Masaharu Anesaki (1873-1949) emprendió una investigación archivística en Europa a partir de I90I, mientras que el lingüista y filólogo Izuru Shinmura (1876-1967), desde 1908. Ello permitió que ambos investigadores dieran a conocer nuevas fuentes occidentales en Japón.

Paralelamente, se llevó a cabo un rescate de las fuentes japonesas. En esta área destacó el lexicógrafo y lingüista Fumihiko Ōtsuki (I847-I928), nieto del confucionista Gentaku Ōtsuki, autor del Kinjōhin. Debido a su vínculo con el clan Date, Fumihiko realizó una revisión del acervo documental de la misma familia y escribió A Brief Account of the Communication of Date Masamune with the Southern Barbarians. En este trabajo, Gentaku describió los tratos que tuvo Masamune con Sotelo, el proyecto de acordar un tratado de intercambios comerciales con Occidente, la misión diplomática de Hasekura y los artículos traídos por él desde Europa. ${ }^{109}$

El entusiasmo por investigar la historia y el arte kirishitan se incrementó notablemente a partir del periodo Taishō (I912-1926) y los principios de la era Shōwa (1926-1989) como consecuencia del 300 aniversario de los martirios de Japón y de la boga namban. En el trasfondo de este revival se percibe el exotismo y romanticismo de la época y los ensayos literarios sobre la cultura namban de Shinmura. ${ }^{10}$ En este contexto cultural se despertó un gran interés

Io8. Yasokaishi Nihon tsūshin, Naojirō Murakami (trad.), Seyū Watanabe (notas), Tokio, Syūhōkaku, I927, vol. I.

I09. Fumihiko Ōtsuki, Date Masamune Namban Tsüshin Jiryaku. A Brief Account of the Communication of Date Masamune with the Southern Barbarians, Tokio, Sakunami Seiryō, I90I.

I IO. El representante de esta corriente literaria fue Izuru Shinmura, quien publicó las siguientes obras: Nambanki, Tokio, Tōadō Shobō, I915; Namban sarasa, Tokio, Kaizōsha, I924; Namban Köki, Tokio, Iwanami Shoten, I925. 
por localizar las fuentes documentales. Así, se sacaron a la luz los testamentos escritos por los kirishitan ${ }^{\mathrm{II}}$ y el calendario litúrgico-santoral descubierto en Takatsuki, Osaka, ${ }^{112}$ además de que se recopilaron las obras literarias escritas por los conversos japoneses. ${ }^{113}$ Asimismo, se descubrieron y se dieron a conocer - y también se falsificaron - varias reliquias y obras cristianas que hasta entonces habían estado ocultas, como La Virgen con escenas de los quince misterios en el Museo de la Universidad de Kioto (fig. 4) y San Francisco Xavier en el Kobe City Museum, pinturas descubiertas en 1920 en la casa del señor Higashi, en Takatsuki, ex territorio del kirishitan daimyō Takayama Ukon (I552-I6I5). ${ }^{\mathrm{II} 4}$ Los hallazgos materiales y los rescates documentales hicieron que los especialistas como Anesaki se interesaran y se aproximaran al contexto histórico de la época de persecución desde una perspectiva histórica, cultural y psicológica. ${ }^{\mathrm{II}}$

En el ámbito arqueológico-artístico, Kōsaku Hamada (I88I-I938) ${ }^{\mathrm{II}}$ fue una figura clave en esta fase inicial del estudio kirishitan; creó una especialización en Early Christian Archaeology \& $\mathrm{Art}^{\mathrm{II} 7}$ y contribuyó al rescate y registro del arte kirishitan con la colaboración de otros estudiosos, como Shinmura y

I I. Minoru Matsuzaki, Kirishitan senketsu isho, Tokio, Kaizōsha, I926, pp. I-3.

I I2. Takatsuki hakken kirishitan bunsho, Sakurai Yasuji (ensayo explicativo), Tokio, Ganshōdō Shoten, I933.

II3. Cfr. Tsunetsugu Muraoka, Kirishitan bungaku shō, Tokio, Kaizōsha, I926.

I 4. Izuru Shinmura, "Christian Relics found at Mr. Higashi's House, North of Takatsuki, Settsu", en Report upon Archaeological Research in the Department of Literature, Kyoto Imperial University, 1922-I923, vol. VII, pp. I-52.

I I5. Masaharu Anesaki, Kirishitan shümon no hakugai to senpuku, Tokio, Dōbunkan, I925; Kirishitan kinsei no shümatsu, Tokio, Dōbunkan, 1926; "Psychological Observations on the Persecution of the Catholics in Japan in the Seventeenth Century", Harvard Journal of Asiatic Studies, núm. I, 1936, pp. 13-27; "Prosecution of Kirishitans after the Shimabara Insurrection”, en Monumenta Nipponica, vol. I, I938, pp. 293-300.

i16. Hamada fue el que guió las investigaciones del arte en el Japón después de la generación de Fenollosa y su discípulo Tenshin Okakura (I862-I9I3). Con base en su sólida formación académica, con estudios en historia del arte en la Universidad Imperial de Tokio y de arqueología en Europa, fundó una escuela de arqueología y arte en el círculo de la Universidad Imperial de Kioto.

I 7. Cfr. Kōsaku Hamada, "Shoki kirisuto-kyo no bijutsu ni tuite", Shūkyō Kenkyū, marzo de I919 y "Kirishitan to geijutsu”, en Kaikoku Bunka, I929. Los artículos de Hamada sobre el estudio kirishitan están recopilados en Kōsaku Hamada, Hamada Kōsaku chosakushū, vol. V: Kirishitan Bunka, Kioto, Dōhōsha, I991. 
4. Anónimo, La Virgen con escenas de los quince misterios, aguada /papel, siglo XVII, $82 \times 64 \mathrm{~cm}$.

Imagen tomada del folleto del Museo de la Universidad de Kioto, 2006. Colección del Museo de la Universidad de Kioto.

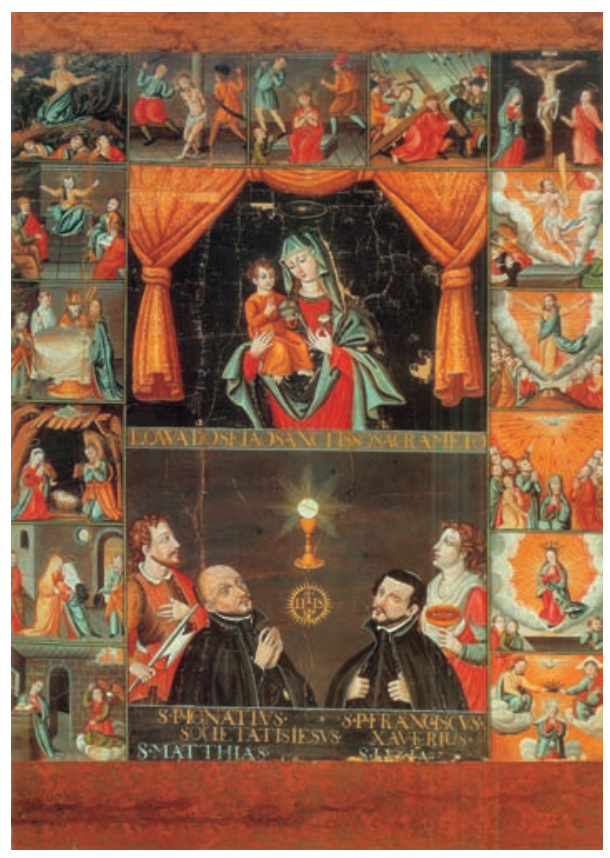

Sueji Umehara (I893-1987). ${ }^{\text {I18 }}$ Las investigaciones de la cultura material kirishitan se caracterizaron desde el principio por el acercamiento estrecho entre la historia del arte y la arqueología, lo cual se debió a la naturaleza misma de este arte que había sido escondido o enterrado a causa de las persecuciones. El vínculo entre dichas disciplinas se manifestó no sólo en la forma de aproximación, sino también en la sistematización de datos. Por tanto, se prefirió agrupar todas las obras (pinturas, esculturas, medallas, rosarios, cuerda de disciplinas, capa pluvial y lápidas funerarias) dentro del concepto de "reliquias kirishitan", utilizando además el vocablo "arte cristiano temprano".

Para el estudio de la historia del arte, una de las aportaciones de Hamada fue reconocer el valor creativo de las obras realizadas por los conversos japo-

I18. Izuru Shinmura y Kōsaku Hamada, "Tomb-Stones of Christians of the Keicho Era, Found in Kyoto and its Neighborhood", en Report upon Archaeological Research in the Department of Literature, Kyoto Imperial University, I922-I923, vol. VII, pp. 53-76; Kōsaku Hamada y Sueji Umehara, "Two Horses Saddles, one with a Coat of Arms consisting of the Monogram of a Christian Name and the Other with Pictures of Portuguese", en ibidem, pp. 77-88. 
neses, ya que señaló una “japonización” al emplear los materiales nativos, además de presentar "aspectos sumamente interesantes”. ${ }^{119}$ Empero, la valoración artística de este autor no implicó el reconocimiento total de las producciones nativas. Así, descalificó las obras transmitidas en el círculo kirishitan de Ikitsuki, en Nagasaki, al aseverar: "La mayoría de estas obras [...] ni merecen ser comentadas con respecto a su valor artístico". ${ }^{20}$ Este juicio de Hamada se debió a la postura de juzgar la plástica japonesa basándose en el criterio eurocéntrico, dado que el citado autor evaluó las hechuras nativas de acuerdo con el grado de la asimilación de las tradiciones artísticas occidentales. Esta aproximación eurocéntrica fue una de las tónicas predominantes dentro del estudio del arte kirishitan durante el siglo pasado.

Asimismo, los padres jesuitas dejaron aportaciones. Joseph Dahlmann (I86I-I930), quien llegó a Japón en 1903 y contribuyó a la fundación de la Universidad Sofía, en I9I3, se interesó por las relaciones culturales, religiosas y artísticas del Japón y Europa entre I542 y I6I4, ${ }^{\mathrm{I} 2 \mathrm{I}}$ en especial en los intercambios culturales y religiosos entre el Japón y Occidente a través de las representaciones pictóricas de los biombos. Con base en el análisis visual, estimó el valor de estas obras como fuentes históricas. Incluso, ante la precisión de los detalles, supuso que los pintores que ejecutaron los biombos debieron haber estado en Nagasaki a principios del siglo XVII para observar los movimientos de intercambios. ${ }^{\mathrm{I} 22}$ Esta idea tuvo posteriormente amplia aceptación.

Georg Schurhammer (I882-I97I), por su parte, dio continuidad a los trabajos que había iniciado Joseph Marie Cros a finales del siglo XIX, ya que editó la Historia do Japão de Fróis, ${ }^{\mathrm{I} 23}$ localizó nuevas fuentes jesuíticas ${ }^{\mathrm{I} 24}$ y, además, se especializó en el estudio biográfico de misioneros destacados, como Fran-

I 19. Kōsaku Hamada, "Nihon kirishitan ibutsu", en Hamada Kōsaku, op. cit., pp. 333-334. I20. Ibidem, p. 338 .

I2I. Joseph Dahlmann, Japans älteste Beziehungen zum Westen I542-I6I4 in zeitgenössischen Denkmälern seiner Kunst: ein Beitrag zur historischen, künstlerischen, religiösen Würdigung eines altjapanischen Bilderschmuckes, Friburgo de Brisgovia, Herder, I923; "The Earliest Intercourse of Japan with the West as Represented by Contemporary Monuments of Japanese Art (I542-I6I4)" [síntesis de la conferencia dictada en 1922], Shigaku zasshi, vol. 34, núm. I, enero de 1923, pp. I-27; "Christianity in Japanese Art. Seven Ancient Screen Paintings with Commentary", Art and Archaeology, vol. XXIII, núm. 4, pp. I69-I78.

I22. Dahlmann, “The Earliest Intercourse of Japan...”, op. cit., pp. I4 y 25.

I23. Schurhammer, Die Geschichte Japans..., op. cit.

I24. Georg Schurhammer, Uma relação inédita do Pe Manuel Barradas S.I. sobre São Francisco Xavier, Lisboa, Centro de Estudos Históricos Ultramarinos, 1958. 
cisco Xavier, con su célebre biografía Der heilige Franz Xaver: der Apostel von Indien und Japan. ${ }^{\mathrm{I} 25}$

\section{Principales perspectivas del estudio kirishitan}

Las líneas de investigación exploradas por los precursores del estudio kirishitan tuvieron amplio desarrollo en distintos campos: filológico, lingüístico, histórico, hagiográfico, cultural, arqueológico y artístico. Incluso se dieron notables pasos dentro del rescate y la investigación de las fuentes japonesas. ${ }^{26}$ No obstante, la narrativa tradicional del siglo pasado se caracterizó por mantener una postura eurocéntrica, ya que se basó en las afirmaciones de los informes y las crónicas occidentales sin ponerlas en tela de juicio. De los autores que construyeron esta versión oficial del siglo kirishitan, se enumera a Charles Ralph Boxer (1904-2000), quien siendo militar estuvo en el Japón y China desde 1930 hasta el término de la segunda guerra mundial y puso empeño en estudiar la historia marítima y colonial de los grandes rivales: Holanda y Portugal. ${ }^{127}$ Entre sus numerosas publicaciones destaca The Christian Century in Japan, I549-I650 (ca. I95I), ${ }^{\mathrm{I} 28}$ obra basada en los documentos procedentes de los archivos de Lisboa y Macao, así como en los informes confidenciales de la Compañía de Jesús en la British Library. De acuerdo con dichas fuentes, Boxer defendió la idea de una "rápida" conversión en Japón. Además, sostuvo que los jesuitas evangelizaron entre los estratos sociales altos, mientras que los mendicantes predicaron entre los pobres. Estas ideas tuvieron aceptación amplia tanto en Japón como a nivel internacional.

En el ámbito académico japonés, Akio Okada (1908-1982), del Historiographical Institute de la Universidad de Tokio, se aproximó al fenómeno kirishitan

I25. Georg Schurhammer, Der heilige Franz Xaver: der Apostel von Indien und Japan, Friburgo de Brisgovia, Herder, I925; Epistolae S. Francisci Xaverii aliaque eius scripta, 2 vols., Schurhammer y Joseph Wicki (eds.), Roma, Monumenta Historica Soc. Iesu, I944-1945.

I26. Cfr. Sakurai, Takatsuki hakken kirishitan bunsho, op. cit.; Marega, Bungo kirishitan shiryō, op. cit.; Zoku Bungo kirishitan shiryō, op. cit.; Kyoko Kawaguchi, "Kirishitan korobi shōmon. Kukamoto Daigaku fuzoku toshokan-zō”, Kumamoto Shigaku, núms. 19-20, diciembre de I960, pp. 39-66.

I27. Dauril Alden, "An Enduring Affair. Charles R. Boxer's Fascination with Japan”, Bulletin of Portuguese-Japanese Studies, vol. I, 2001, p. I5 I.

I28. Charles Ralph Boxer, The Christian Century in Japan, I549-I650 [ca. I95 I], Berkeley, University of California Press, 1967. 
desde el punto de vista de la historia cultural-cotidiana denominada füzoku. Okada ahondó en los problemas morales con que los misioneros tuvieron que enfrentarse en la sociedad japonesa, como la sodomía, el aborto y el infanticidio. Asimismo, estudió la transmisión de las ciencias y la cultura occidentales en esta época, además de los aspectos históricos de las misiones, como la distribución de las fundaciones jesuíticas, diferentes métodos de evangelización y recepciones del cristianismo según los estratos sociales. ${ }^{\text {I29 }}$

Arimichi Ebisawa (1910-1992) fue otra figura central en el estudio kirishitan en la posguerra; fundó The Society of Historical Studies of Christianity en I949 y ahondó en los tráficos e intercambios científico-culturales impulsados por los misioneros. Estudió la circulación de los libros, así como la difusión de los conocimientos relativos a la medicina, la astronomía, la matemática, la ingeniería y el arte occidentales. ${ }^{130}$ También contribuyó a la investigación de las fuentes sino-japonesas. ${ }^{\mathrm{I} I \mathrm{I}}$

Kiichi Matsuda (I92I-1997) fue otra autoridad del estudio namban; contribuyó al rescate, la traducción y publicación de los documentos sobre las relaciones exteriores del Japón, principalmente las fuentes relacionadas con las misiones jesuíticas, resguardadas en los archivos de Filipinas, Macao y Europa. Entre sus hallazgos documentales destaca un biombo de la Biblioteca de Evora, donde estaban insertados varios documentos procedentes del Japón, como "El catecismo de Japón" escrito por Valignano y traducido al japonés, las cartas de Organtino, ejercicios de caligrafía y grafiti. ${ }^{\mathrm{I} 2}$ Asimismo, escribió varios ensayos acerca de la documentación y las misiones de la Compañía de Jesús en Japón. ${ }^{133}$

I29. Okada comenzó a presentar una serie de artículos sobre el estudio namban desde I940: Akio Okada, "Namban-ji to byōbu", Gasetsu, núm. 43, julio de 1940; "Kirishitan shinkō shūzoku no shakaishiteki igi", Rekishi Chiri, vol. 76, núms. 2, 3 y 4, de agosto a octubre de 1940; "Fukyō kikan no bunpu ni tsuite", Kirishitan Kenkyu, núm. 3, julio de 1948. Los ensayos de Okada relacionados con este tema están compilados en Akio Okada, Kirishitan shinkō to shüzoku. Okada Akio chosaku shū I, Kioto, Shibunkaku Shuppan, 1983, y Kirishitan füzoku to Namban bunka. Okada Akio chosaku shü II, Kioto, Shibunkaku Shuppan, I983.

I30. Arimichi Ebisawa, Namban bunka - Nichiō bunka köshō-, Tokio, Shibundō, 1958.

I3I. Arimichi Ebisawa, Christianity in Japan: A Bibliography of Japanese and Chinese Sources, Tokio, Universidad Cristiana Internacional, I960.

132. Arimichi Ebisawa y Kiichi Matsuda, Portugal Evora shinshutsu byōbu bunsho no kenkyü, Tokio, Natsumesha, 1963.

133. Kiichi Matsuda, Namban shiryō no hakken. Yomigaeru Nobunaga jidai, Tokio, Chūō 
Yakichi Kataoka (1908-1980), originario de Nagasaki, se aproximó al estudio kirishitan desde la perspectiva de la historia regional. Ahondó en el estudio de fumi-e desde el punto de vista histórico, social y cultural. Así, aclaró la forma de organizar las ceremonias de fumi-e, así como distintos lugares donde se llevaron a cabo las prácticas de fumi-e conforme a los estratos sociales. ${ }^{\mathrm{I} 4}$ También estudió el acontecimiento de Urakami yonban kuzure, la cuarta opresión de los kirishitan de la villa de Urakami, Nagasaki, en I869, la última y más grande de las medidas anticristianas aplicadas en el periodo Meiji. ${ }^{135}$

Una de las líneas de investigación desarrolladas por historiadores seculares japoneses, como Kōichirō Takase (I936-) y Takashi Gonoi (I94I-), fue aclarar cuestiones políticas, económicas, culturales y lingüísticas. ${ }^{136}$ En especial, Takase aclaró la base financiera de la Iglesia para realizar las misiones en Asia del Éste, así como los problemas de las negociaciones y los conflictos políticos y económicos entre los líderes de las misiones y las autoridades civiles japonesas. ${ }^{\mathrm{I} 7}$

Los estudiosos jesuitas, por su parte, se empeñaron en el estudio de la historia apostólica de su propia institución. Johannes Laures (I89I-I959) contribuyó a la conformación del Kirishitan bunko, acervo documental-bibliográfico especializado en las misiones católicas de Japón en la Universidad Sofía. ${ }^{138}$ Además, realizó un estudio histórico general sobre las actividades misioneras en The Catholic Church in Japan..., ${ }^{139}$ construyendo una narración apologética de los jesuitas.

Joseph Franz Schütte (1906-I98I) fue el historiador que más aportó a los rescates documentales, tal como lo muestra su Introductio ad historiam Societa-

kōronsha, I99I [primera ed. I964]; Kinsei shoki Nihon kankei Namban shiryō no kenkyū, Tokio, Kazama Shobō, 1967.

I34. Yakichi Kataoka, Fumi-e. Kinkyō no rekishi [1969], Tokio, Nihon Hōsō Shuppan Kyōkai, I975.

135. Yakichi Kataoka, Urakami yonban kuzure, Tokio, Chikuma Shobō, 1963.

I36. Takashi Gonoi, Tokugawa shoki kirishitan shi kenkyū, Tokio, Yoshikawa Kōbunkan, 1983.

I37. Kōichirō Takase, Kirishitan jidai no kenkyū, Tokio, Iwanami Shoten, 1977.

138. Johannes Laures, The Ancient Japanese Mission Press, reimpreso en Kirishitan bunko, parte I, Tokio, Universidad Sofía, 1940; Kirishitan Bunko: A Manual of Books and Documents on the Early Christian Mission in Japan, Tokio, Universidad Sofía, 1957; An Ancient Document on the Early Intercourse between Japan and the Philippine Islands, separata de Cultura Social, vol. XXIX, núms. 337-338, I94I.

I39. Johannes Laures, The Catholic Church in Japan: A Short History, Tokio, Charles E. Tuttle, I954. 
tis Jesu in Japonia, I549-1650, ${ }^{140}$ donde recopiló extensos datos inéditos acerca de las actividades de la Compañía de Jesús en tierra japonesa. También publicó estudios sobre la historia de la conformación de los archivos jesuíticos, los cuales sufrieron una serie de vicisitudes y traslados de los materiales procedentes del Lejano Oriente a causa de las circunstancias históricas de la Compañía de Jesús tanto en Asia como en Europa. ${ }^{\mathrm{I}}{ }^{\mathrm{I}}$ Asimismo, Hubert Cieslik (19141998), jesuita, dedicó su vida sacerdotal en Hiroshima, entre 1945 y 1949, a realizar los rescates documentales y las investigaciones históricas de la misión jesuítica en dicha provincia. ${ }^{142}$ Además, fue pionero en investigar a los sacerdotes japoneses, como Pedro Kasui (I587-I639). ${ }^{143}$

Jesús López Gay aportó diversos estudios histórico-religiosos. Por una parte, dilucidó los volúmenes de que disponía la primera biblioteca jesuítica de Bungo y analizó la influencia que dichos libros ejercieron en la labor pastoral y científica de los primeros misioneros jesuitas en Japón. ${ }^{\mathrm{I} 44}$ Asimismo, aclaró la manera como los jesuitas adaptaron las costumbres y tradiciones nativas en distintos niveles: cultural, evangélico y litúrgico. A su juicio, en la misión de Japón no se pudieron utilizar normas establecidas a priori, puesto que se optó por una adaptación positiva. ${ }^{145}$

I40. Joseph Franz Schütte, Introductio ad historiam Societatis Jesu in Japonia, I549-1650, Roma, Institutum Historicum Societates Jesu, 1968.

I4I. Joseph Franz Schütte, El "Archivo del Japón": vicisitudes del archivo jesuitico del Extremo Oriente y descripción del fondo existente en la Real Academia de la Historia de Madrid, Madrid, Real Academia de la Historia (Archivo Documental Español, XX), 1964; Documentos sobre el Japón conservados en la colección "Cortes" de la Real Academia de la Historia, Madrid, Imprenta y Editorial Maestre, I96r; "Documentos del 'Archivo del Japón' en la Biblioteca Nacional madrileña”, Missionalia Hispanica, año XXVII, núm. 79, I970, pp. 59-88.

I42. Hubert Cieslik, "Die Jesuitenmission in Hiroshima im I7. Jahrhundert", Archivum Historicum Societatis Jesu, núm. 22, 1953, pp. 239-275; Geibi Kirishitan shiryö: Sources and Documents Concerning the History of Kirishitan in the Provinces of Aki and Bingo, Tokio, Yoshikawa Kōbunkan, I968.

I43. Hubert Cieslik, "P. Pedro Kasui (I587-I639): der letzte japanische Jesuit der Tokugawa-Zeit", Monumenta Nipponica, vol. I5, núms. I-2, abril-julio de I960, pp. 35-86; "The Training of a Japanese Clergy in the Seventeenth Century", en Studies in Japanese Culture, 1963, pp. 4I-78; Kirishitan jidai no höjin shisai, Tokio, Kirishitan Bunka Kenkyukai, I98I; Kirishitan jidai no nihon-jin shisai, Tokio, Kyobunkan, 2004.

I44. Jesús López Gay, S.J., "La primera biblioteca de los jesuitas en el Japón (I556): su contenido y su influencia”, Monumenta Nipponica, vol. XV, núms. 3-4, I959-1960, pp. I42-I7I.

I45. Jesús López Gay, La liturgia en la misión del Japón del siglo XVI, Roma, Libreria dell'Università Gregoriana, I970, p. 20. 
A finales de los años sesenta, en el ámbito académico internacional, comenzaron a surgir reflexiones críticas con respecto a la historiografía tradicional basada en las fuentes jesuíticas y a abrirse nuevos horizontes. Así, George Elison, en su "Deus Destroyed", se aproximó a problemas como la aceptación del cristianismo y las formas del rechazo de dicha religión en Japón desde un punto de vista más cercano al de los japoneses. ${ }^{146}$ Ante la postura tradicional de comparar y encontrar una analogía entre la introducción del cristianismo en Japón y la historia de la Iglesia primitiva — postura que se apoyaba en gran parte en los cronistas que habían equiparado de manera alegórica las persecuciones y martirios de Japón y la cristiandad primitiva de Occidente-, el autor advirtió que en realidad hubo más diferencias que similitudes. En efecto, la complejidad dogmática, la política evangélica y el sofisticado sistema organizativo institucional de la misión católica de Japón — que coincidió con el Concilio de Trento (I545-I563) — no tuvieron nada que ver con las condiciones de la Iglesia primitiva. De hecho, las únicas similitudes se encontrarían en los problemas básicos que toda misión encuentra para ganar fieles en un mundo ajeno, aunque en Japón la filosofía cristiana era totalmente desconocida a diferencia de Occidente, que desde tiempos remotos se había alimentado de los pensamientos religiosos de Medio Oriente. ${ }^{\mathrm{I}}{ }^{77}$ Asimismo, Elison puso en duda la postura eurocéntrica de considerar la prohibición cristiana como una "tragedia" ${ }^{48}$ de acuerdo con la visión nativa.

Por otra parte, Lothar Knauth fue pionero en desarrollar una línea de investigación transpacífica, en especial, la expansión ibérica en Asia, con su disertación "Pacific Confrontation: Japan Encounters the Spanish Overseas Empire (I542-I639)" I49 El autor se aproximó a la historia de la misión católica en Japón reconstruyendo las relaciones políticas, culturales y religiosas del lado del Pacífico: Japón y la Corona española (Filipinas y la Nueva España). A su juicio, la trascendencia y consecuencia histórica de la expansión ibérica hacia el este no consistió sólo en explorar nuevas rutas marítimas en pro de la mundialización política, económica, cultural y religiosa, sino también en asentar bases para la posterior expansión estadounidense, que se convirtió

I46. George Elison, "Deus Destroyed. The Image of Christianity in Early Modern Japan", tesis doctoral, Cambridge, Massachusetts, Universidad de Harvard, 1969.

I47. Elison, "Deus Destroyed...", op. cit., pp. I3-I4.

I48. Laures, The Catholic Church in Japan..., op. cit., p. V.

I49. Lothar Knauth, "Pacific Confrontation: Japan Encounters the Spanish Overseas Empire (I542-I639)”, tesis doctoral, Cambridge, Massachusetts, Universidad de Harvard, I970. 
en su "heredera" y se hizo "a costa de la experiencia hispánica". ${ }^{50}$ Además, a diferencia de la postura tradicional de interpretar el fracaso de las misiones en Japón como un asunto negativo, Knauth lo consideró una base importante para la futura construcción de la nación moderna de Japón. La aproximación transpacífica emprendida por dicho historiador cobró importancia en los ańos setenta, ya que se organizó un congreso internacional: La expansión hispanoamericana en Asia: siglos XVI y XVII (I976), en el que se trataron los vínculos entre la Nueva Espańa y Oriente acerca de las fuentes históricas, las misiones y el arte. ${ }^{\text {I5I }}$

En las últimas décadas han surgido otras maneras de tratar el tema kirishitan. Andrew C. Ross, por ejemplo, se aproximó de manera sinóptica al fenómeno de las misiones católicas en Japón y China. ${ }^{152}$ Ello ha ayudado a tener una visión más cercana de la época, ya que esclarece que los misioneros hayan concebido las empresas apostólicas en Asia del este como un proyecto unido. Por otra parte, cuestiona la postura convencional en que se interpreta la historia del siglo kirishitan, en el cual se encontrarían los éxitos de la labor de los jesuitas desde sus primeros tiempos y la "heroicidad" y "grandiosidad" de los misioneros. Así, Ikuo Higashibaba y Shinzō Kawamura se han aproximado a la historia kirishitan desde el punto de vista nativo, en especial, centrándose en las comunidades kirishitan de los estratos sociales comunes, que habían sido ignoradas hasta entonces. Higashibaba, siendo especialista en la religión, rescató las creencias y experiencias religiosas cotidianas de los kirishitan ordinarios y demostró que la religiosidad de estos conversos fue muy distinta de las afirmaciones de los cronistas. ${ }^{\mathrm{I}} 53$ Kawamura, por su parte, ahondó en la organización de la comunidad kirishitan y aclaró la manera como la Iglesia japonesa se apropió del sistema de las instituciones budistas. ${ }^{154}$

I50. Lothar Knauth, Confrontación transpacifica: el Japón y el nuevo mundo hispánico, $1542-$ I639, México, Universidad Nacional Autónoma de México-Instituto de Investigaciones Históricas, 1972 , p. 17.

I5I. Ernesto de la Torre Villar (comp.), La expansión hispanoamericana en Asia: siglos XVI y XVII, XXX Congreso Internacional de Ciencias Humanas en Asia y África del Norte, México, del 3 al 8 de agosto de 1976, México, Fondo de Cultura Económica, 1980.

152. Andrew C. Ross, A Vision Betrayed: The Jesuits in Japan and China 1542-1742, Edimburgo, Edinburgh University Press, 1994 .

I53. Ikuo Higashibaba, "Beliefs and Practices of Lay Christians in Early Modern Japan", tesis doctoral, Berkeley, Graduate Theological Union, 1996; Christianity in Early Modern Japan: Kirishitan Belief and Practice, Leiden/Boston, Brill, $200 \mathrm{I}$.

154. Shinzō Kawamura, Kirishitan shinto soshiki no tanjō to henyō "konfurariya" kara "kon- 


\section{Avances del estudio del arte kirishitan}

Si bien Fenollosa fue el primero en interesarse por la influencia del arte europeo durante el periodo Momoyama, las aproximaciones más especializadas al arte kirishitan surgieron dentro del círculo del arqueólogo Hamada, en Kioto, antigua región de Cami, ${ }^{155}$ donde se hallaban diversos vestigios por haber sido una de las principales sedes misioneras. De la misma forma, Nagasaki se convirtió en otro centro del estudio kirishitan desde la década de 1920, ya que Tokihide Nagayama (I867-I935) y Tokutarō Nagami (I890-1950) se aproximaron al tema desde la perspectiva de la historia regional. Nagayama, así como el primer director de la Nagasaki Prefectural Library, elaboró diversos catálogos del arte kirishitan que se conservaba en su localidad. ${ }^{156}$ Estos registros, con el tiempo, adquirieron un gran valor testimonial, dado que las obras que formaban parte de la colección de la catedral de Urakami se perdieron a causa de la explosión de la bomba atómica en 1945 .

Nagami, en cambio, invirtió su fortuna en coleccionar los documentos relacionados con Nagasaki, así como los biombos namban. Hay que advertir que el desarrollo del estudio del arte kirishitan en el siglo xx estuvo íntimamente ligado al coleccionismo, ya que esto permitió que se organizaran exposiciones y se dieran a conocer las obras al público general. ${ }^{57}$ La aportación de Nagami fue realizar un análisis iconográfico de los biombos namban y postular que las

furariya” he, Tokio, Kyōbunkan, 2003; "An Evaluation of Valignano's Decision-making from the Viewpoint of Japanese Society", en Integration and Division between Universalism and Localism in Jesuit Mission Reports and Histories: Sophia University International Colloquium 2005 Report, Tokio, The Sophia University Research Group for Jesuit Mission Reports and Histories, 2006, pp. IOI-II7.

I55. La zona de evangelización jesuítica durante los primeros 50 años no abarcó todos los territorios actuales del Japón, sino la mitad occidental del país, es decir, desde Kyushu hasta Kansai. Los jesuitas dividieron esta región en tres jurisdicciones misionales: Cami, Ximo y Bungo. Cami (Kami 上 en la transcripción actual), cuyo sentido etimológico es "arriba”, designaba la jurisdicción misional de Miyako (Kyoto) y sus alrededores, mientras que Ximo (Shimo 下), que significa "abajo", implicaba la parte oeste de Kyushu, que incluía Arima, Amakusa, Nagasaki, Ōmura, Firando (Hirado) y algunos otros feudos periféricos. Bungo es el antiguo nombre de la actual prefectura de Ōita.

I56. Tokihide Nagayama, Collection of Historical Materials Connected with the Roman Catholic Religion in Japan, Nagasaki, Taigai Shiryō Hōkan Kankōkai, ı925; An Album of Historical Materials Connected with Foreign Intercourse, Nagasaki, Fujiki Hirohidesha, 1932.

157. Tokutarō Nagami, Namban bijutsu shü, prefacio de Izuru Shinmura, Tokio, Nambankai, 1928. 
obras que no mostraban elementos kirishitan - como las representaciones de las iglesias y de los misioneros- pudieron ser producciones del periodo de la prohibición cristiana. Asimismo, propuso la hipótesis de que los pintores que representaron de manera detallada los temas kirishitan debieron de haber sido personas que tenían acceso libre a las iglesias y pudieron observar la liturgia ahí impartida. Incluso planteó que debieron de haber existido pintores católicos. ${ }^{158}$ Estas ideas gozaron de amplia aceptación. Sin embargo, este autor menospreció a la vez el arte kirishitan, ya que los grabados de cobre impresos en Arie mostraban una "belleza histórica" pero eran "obras infantiles". 159

Ante la tendencia de reconocer sólo el valor histórico de las obras, Tei Nishimura (1893-I96I) contribuyó con sus análisis, realizados desde el punto de vista de la historia del arte. Su Namban bijutsu fue una compilación de diversos artículos presentados anteriormente y mostró resultados de investigaciones realizadas entre 1925 y 1958 acerca de técnicas y materiales, fuentes figurativas, análisis formal e iconográfico de las pinturas, fumi-e, hostiarios de laca, cerámicas y guarda-espadas con cruz. Además, ahondó en las actividades artísticas de la Compañía de Jesús en Japón y China.

Por innovador que fuese su estudio, tampoco este autor se salvó de la aproximación eurocéntrica de su tiempo. Así, valoró más positivamente las obras kirishitan que presentaban mayor semejanza a las obras europeas y al mismo tiempo descalificó aquellas que no iban acorde con los cánones occidentales; tal fue el caso de las imágenes de los kirishitan ocultos en Ikitsuki, a las cuales atribuyó valor histórico y devocional, pero aseveró que como "obra del arte" no valían nada, ${ }^{\mathrm{I} 60}$ como había afirmado Hamada. En suma, uno de los problemas del estudio tradicional consistió en analizar las expresiones plásticas japonesas con la idea elitista de "obra del arte", además de calificar el valor artístico de la pieza conforme al criterio europeo. Lo anterior no fue, desde luego, un problema exclusivo de la historiografía japonesa, sino, más bien, un problema generalizado, como sucedió con las interpretaciones del arte virreinal en América.

Asimismo, en la primera mitad del siglo xx, se interpretó el arte kirishitan sometiéndolo a las taxonomías de "estilo occidental" y "estilo japonés".

158. Tokutarō Nagami, Namban byobu taisei, Tokio, Kōgeisha, I930, p. 23.

159. Tokutarō Nagami, Nagasaki no bijutsu-shi, Kioto, Rinkawa Shoten, I974, p. 7 [primera ed. 1927].

I60. Tei Nishimura, Namban bijutsu, Tokio, Kōdansha, I958, p. 2 I. 
Mas, en sentido estricto, en lo "japonés" pueden manifestarse a la vez elementos occidentales y viceversa, de tal forma que se ha observado la presencia de las tradiciones plásticas japonesas en las técnicas, los materiales, la configuración lineal y los motivos decorativos de las pinturas agrupadas en el concepto de "estilo europeo". ${ }^{\text {6r }}$ Ello mostró el límite de la aproximación convencional basada en la clasificación estilística.

A partir de la década de 1970, el estudio del arte kirishitan tomó direcciones diferentes con el surgimiento de un mayor número de monografías y cambios en las interpretaciones. En el área de la pintura, Mitsuru Sakamoto (1932-) contextualizó las obras en el trasfondo histórico de la Contrarreforma y su consecuente evangelización mundial. A su juicio, la política postridentina repercutió en Japón en el sentido de que el arte estuvo subordinado al servicio de la Iglesia, ya que las imágenes, antes de ser expresión artística libre, fueron medio de evangelización y de culto. En otras palabras, el arte no tuvo un valor intrínseco independiente, sino que cobró su sentido con la función religiosa. Como consecuencia, la creatividad se limitó. Asimismo, Sakamoto distinguió las manifestaciones japonesas del arte postridentino europeo: éste supo aprovechar en mayor medida las "restricciones" de dicha política con relación a las imágenes y llegó a crear expresiones de gran esplendor en los siglos XVII y XVIII, mientras que el contexto cultural-artístico de Japón fue totalmente distinto. De hecho, el cristianismo fue una religión nueva y además las técnicas pictóricas, como claroscuro, volumen, dibujo, anatomía, perspectiva y óptica, no fueron soluciones artísticas conocidas y difundidas en Japón. Aunque se estableció una escuela de pintura en el círculo jesuítico con la llegada de Nicolao en 1583 , el objetivo central no fue proporcionar una educación artística integral para que aprendieran a crear artes liberales, sino satisfacer las demandas de las imágenes de carácter religioso-devocional. Además, los alumnos del seminario estaban internados en las residencias y contribuían en las producciones colectivas. Lo anterior remitía al sistema tradicional de entrenamiento de los discípulos, pero reorganizado de acuerdo con las necesidades de los misioneros. Por tanto, Sakamoto consideró que dicha escuela de pintura no fue una academia en el sentido moderno, sino que debió funcionar como taller, donde el maestro transmitía sus conocimientos y habilidades técnicas a los discípulos. De esta forma, advirtió el problema conceptual de gagakusha, 画学舎, 
"casa de la ciencia de pintura", palabra que surgió al traducir al japonés Malerschule, de Schurhammer, y de Jesuit school of painting, de Boxer. ${ }^{\mathrm{I} 2}$

Esta contextualización del arte católico japonés en las circunstancias formativas y laborales de los alumnos del seminario hizo que Sakamoto no juzgara las obras kirishitan de manera despectiva, a diferencia de los estudiosos anteriores. En efecto, revaloró la capacidad de aprendizaje de los alumnos japoneses, que retomaron e integraron como "patrón" o maniera los motivos y composiciones de los grabados sin tener los conocimientos técnicos básicos de la pintura europea. ${ }^{163}$ De este modo, dicho autor ubicó el arte kirishitan bajo el concepto de "manierismo". En su definición, éste correspondía al estilo de la fase final del Renacimiento o antes de la formación del barroco y era una corriente artística dada en un periodo en el que todavía no se formaba "un estilo estable" del arte "contrarreformista". ${ }^{164}$ Cabe mencionar que desde la visión de este autor, el "manierismo" era una expresión virtuosa a diferencia de otros estudiosos como Akiyama, para quien dicho concepto significaba algo "carente de la originalidad artística". ${ }^{165}$

A su vez, otra contribución de Sakamoto fue coordinar los proyectos de elaboración de los catálogos: Bulletin of the National Museum of Japanese History. An Essay of Catalogue Raisonné of Namban Art ${ }^{166}$ y A Catalogue Raisonné of Namban Screens. ${ }^{167}$ En la primera obra, dicho autor presentó un ensayo donde se sintetizaban las conclusiones de los estudios realizados desde la década de 1970. Así, atribuyó la introducción y transmisión de las tradiciones pictóricas europeas a las labores de la Compañía de Jesús y reafirmó la existencia del fenómeno que se podría denominar "la escuela de pintura jesuítica" en Japón. ${ }^{\text {168 }}$

I62. Mitsuru Sakamoto, "Kirishitan bijutsu to Kyushu", en Kyushu no kaiga to tōgei. Kyushu bunka ronshū 5, Fukuoka unesco Kyokai (ed.), Tokio, Heibonsha, 1975, pp. 20I-203.

163. Ibidem, pp. 217-218.

164. Ibidem, p. I85.

165. Akiyama, op. cit., p. 26.

166. Mitsuru Sakamoto et al., Bulletin of the National Museum of Japanese History. An Essay of Catalogue Raisonné of Namban Art. Part One: Japanese Early European-Style Painting, Sakura, Chiba, National Museum of Japanese History, vol. 75, marzo de 1997.

167. Mitsuru Sakamoto et al., A Catalogue Raisonné of Namban Screens, Tokio, Chūō Kōron Bijutsu Shuppan, 2008.

I68. Mitsuru Sakamoto, "Namban Art and European-style Painting", Bulletin of the National Museum of Japanese History, op. cit., p. I4. 
Por lo que corresponde a la arquitectura católica, Ishikawa fue el primero en abrir una línea de investigación especializada en la "arquitectura kirishitan" al acuñar este término, ${ }^{169}$ aunque el tema en cuestión lo habían tratado antes distintos autores y el principal debate se había centrado en cuestiones estilísticas. De hecho, Murakami postuló en I9I I que los edificios católicos japoneses no eran a la occidental, como mostraban las ilustraciones de Ciappi, sino a la japonesa. ${ }^{170}$ Esta teoría fue legitimada por Hamada, Shinmura y Okamoto, quienes se apoyaron en las referencias documentales de "edificios de madera”, así como en las representaciones pictóricas de los biombos y El templo Namban de Miyako de Kanō Sōshū (fig. 5). ${ }^{17 \mathrm{I}}$ Empero, al mismo tiempo hubo otra corriente que sostenía la existencia de edificios de tipo occidental. El representante de esta postura fue Kōichi Satō, doctor en ingeniería, quien aseveró sin fundamento que Francisco Xavier trajo consigo la edición italiana de De architectura de Vitruvio y De re adificatoria de Alberti, obras que habrían sido aprovechadas para proyectos constructivos posteriores. ${ }^{172}$ Ante esta controversia, Ishikawa opinó que en las primeras décadas de las misiones se reutilizaron los templos budistas abandonados, mientras que aproximadamente a partir de 1580 se pudo intentar el levantamiento de construcciones a la manera occidental. En efecto, en la carta de I603 se mencionó la existencia de una arquería en la iglesia nueva de Tamba. A este respecto, Ishikawa consideró, sin basarse en fuente alguna, que se pudo haber aplicado el sistema constructivo de materiales como el ladrillo para levantar un arco. Asimismo, dicho autor puso de manifiesto que debido a la falta de ingenieros que poseyeran el conocimiento arquitectónico europeo y a la inexperiencia de los obreros japoneses, las obras kirishitan pudieron resultar "de estilo ecléctico de lo occidental y lo japonés”, como sucedió al principio del periodo Meiji. ${ }^{173}$

169. Tōru Ishikawa publicó una serie de artículos sobre la arquitectura kirishitan en la revista Nihon kenchiku gakkai kenkyu, núms. 3-18, I949-1952.

I70. Naojirō Murakami, "Azuchi-Momoyama jidai no kirisutokyō" (I9II), citado por Ichio Kuga, Bunroku ni nen Amakusa gakurin zō: Kirishitan Amakusa tōban no kenkyu narabi Kanō Motohide hitsu senmen zu no ichi kōsatsu, Osaka, Sōjinsha, I963, p. 95.

I7I. Yoshitomo Okamoto, Momoyama jidai no kirisuto-kyō bunka, Tokio, Tōyōdō, I948, p. 23; Namban byōbukō, Tokio, Shōrinsha, I955, pp. 58-62.

I72. Kōichi Satō, "Zegōshi”, Gakugai, agosto de 1939, citado por Ebisawa, Namban bunka —Nichiō bunka köshō-, op. cit., p. 99.

I73. Tōru Ishikawa, "Wagakuni kirisuto-kyōkaidō no kenchikushiteki kenkyū", Nihon Kenchiku Gakkai Kenkyu Hōkoku, núm. 3, octubre de 1949, pp. I28-I29. 


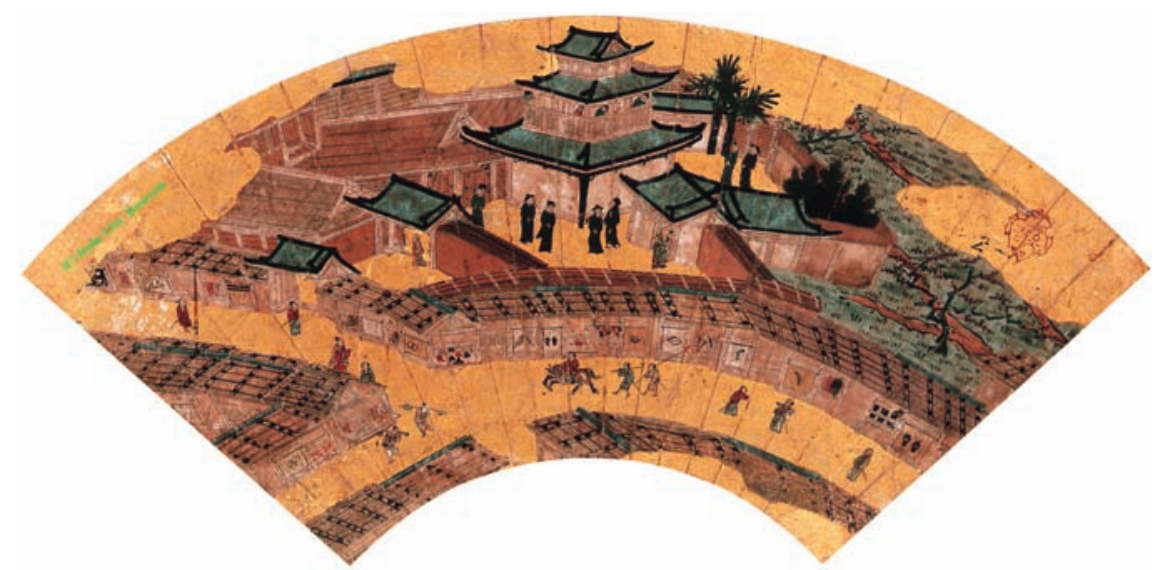

5. Kanō Sōshū, El templo Namban de Miyako, ca. I578-1587. Imagen tomada del sitio http://www.city.kobe.lg.jp/culture/culture/institution/museum/meihin/o45.html, el I9 de abril de 2or i. Colección del Museo de la Ciudad de Kobe.

La carencia de vestigios materiales de la arquitectura condujo a que los debates se centraran en cuestiones meramente hipotéticas sobre los estilos. Los autores que sustentaron el "estilo occidental" de la arquitectura kirishitan, como Ebisawa y Kuga, retomaron la idea especulativa de Satō acerca de la introducción de los tratados de Vitruvio y Alberti. ${ }^{174}$ Además, sacaron a colación las ilustraciones del libro de Ciappi, que representan a la manera europea los seminarios de Arima y Azuchi, el colegio de Funai y la casa de probación de Usuki fundadas hacia I580 y I58I, así como la capilla de cueva de Taketa en Ōita y la fachada de la iglesia de São Paulo en Macao, en cuya fábrica intervinieron los japoneses inmigrados. Eso probaría que los japoneses poseían conocimiento de técnicas constructivas europeas. ${ }^{175}$ No obstante, al menos en lo tocante a los grabados de Ciappi, Arai puso en duda su valor histórico-testimonial. En opinión de esta autora, los niños embajadores enviados por los kirishitan daimyō de Kyushu en 1582 pudieron haberle obsequiado a Gregorio XIII dibujos que ilustraban de manera bastante fiel edificios reales. Pero ello no garantizaba que dichas imágenes hubieran servido de fuente visual para

174. Ebisawa, Namban bunka — Nichiō bunka kōshō-, op. cit., p. 99; Kuga, Bunroku ni nen Amakusa gakurin zō, op. cit., p. 96.

175. Ichio, Bunroku ni nen Amakusa gakurin zō, op. cit., pp. 203-204. 
ilustrar el libro en cuestión. En efecto, en las láminas de este texto se observa la reutilización de las mismas placas, por lo que los colegios fundados en distintas partes del mundo se asemejan entre sí. ${ }^{176} \mathrm{~A}$ través de la explicación de los métodos y las técnicas de las imágenes en la imprenta, la autora pudo desmitificar la veracidad de los grabados como fuente histórica.

Desde la década de 1970, el estudio de la arquitectura kirishitan dio un paso notable gracias a la intervención de especialistas formados en distintas disciplinas. Los estudios anteriores se limitaron a proporcionar datos históricos o discusiones estilísticas, mientras que Yamaguchi y Miyamoto, formados como ingeniero y arquitecto respectivamente, ahondaron en el tema desde el punto de vista constructivo. Incluso este segundo autor reconstruyó la distribución y planta arquitectónica entrecruzando los datos derivados de las fuentes históricas y de las excavaciones arqueológicas. ${ }^{177}$ Así, en el caso de la iglesia de Santo Domingo en Nagasaki, la propuesta de Miyamoto presentada en $2004^{178}$ coincidió a grandes rasgos con la anterior reconstrucción gráfica realizada por Pacheco con base en las descripciones de los documentos. ${ }^{179}$

Pese a estos avances, aún quedan problemas pendientes. Principalmente, hasta ahora se ha interpretado el fenómeno arquitectónico de manera esquemática. Debido a las normas constructivas dictadas por Valignano, se ha reforzado la idea de que con la primera llegada de dicho visitador en I579 se dio un cambio radical en la arquitectura jesuítica; en la primera fase (I549-I579) se habría edificado de acuerdo con las experiencias e intenciones propias de los padres y devotos sin tener una homogeneidad en el programa arquitectónico, mientras que en la segunda (I579-I6I4) hubo mayor orden debido a las

176. Toshi Arai, "Pictures of the Jesuit Schools in Japan in Ciappi’s book", Biblia. Bulletin of Tenri Central Library, núm. I9, junio de 196I, pp. I2-I6. Las versiones de las ilustraciones de las escuelas jesuíticas presentadas por Ciappi se publicaron en Francesco BoncompagniLudovisi, Le prime due ambasciate dei giapponesi a Roma (I585-1615) con nuovi documenti, Roma, Forzani, I904.

177. Kōichi Mori, Kyoto-shi Chūkyō-ku Ubayanagi-machi iseki (Namban-ji ato) chōsa gaihō, Kyoto, Doshisha Daigaku Bungakubu Bunka Gakka, 1973; Katsuyama-machi iseki: Nagasaki-shi Sakura-machi shōgakkō shinsetsu ni tomonau maizō bunkazai hakkutsu chōsa hōkokusho, Nagasaki, Nagasaki-shi Kyōiku Iinkai, 2003.

I78. Kenji Miyamoto, "The Restoration of Santo Domingo Church in Nagasaki", Intercultural Studies, núm. 8, 2004, p. 66.

I79. Diego Pacheco, "Nagasaki no kyōkai (I567-1620)", Nagasaki Dansō, núm. 58, noviembre de 1975, artículo reimpreso en Kyushu kirishitan shi kenkyu, Tokio, Kirishitan Bunka Kenkyukai, 1977, p. I46. 
instrucciones de Valignano. ${ }^{180}$ Así, se ha tendido a creer que en todos los edificios de la segunda fase se respetaron las reglas edificatorias del visitador.

En lo que atañe a la laca namban, el estudio de las piezas destinadas a la exportación surgió en el ámbito académico occidental, en especial en el área de investigación de las lacas exportadas mediante la Compañía Holandesa de las Indias Orientales. ${ }^{\text {I8I }}$ Esta aproximación tuvo aceptación amplia a nivel internacional y fue continuada por autores como Martha Boyer (I9II-I995), precursora en el estudio de las técnicas y formas de las piezas del maque japonés que formaban parte de las colecciones de los museos europeos. A juicio de esta autora, la laca namban se caracterizaba por el uso de polvo de oro y plata, la aplicación del método coreano de incrustar concha nácar (técnica llamada raden) y los motivos dentellados y sarmientos, que tenían su origen en Asia del Oeste y fueron transmitidos vía China, ${ }^{182}$ de tal forma que apuntó la complejidad de la dependencia artística de este arte, algo que luego se convirtió en el centro de todas las discusiones.

En el ámbito japonés, si bien los registros sobre la laca se iniciaron desde el tiempo de Hamada y Shinmura dentro de la categoría de "reliquias kirishitan", el interés aumentó después de la segunda guerra mundial, cuando comenzaron a regresar a Japón las piezas que habían salido a la venta en el mercado del arte internacional. El coleccionista del arte Yoshirō Kitamura fundó la Gallery Namban en Osaka en 1967 y publicó catálogos para dar a conocer el acervo personal, como biombos, pinturas y lacas. ${ }^{183}$ Para la difusión y el desarrollo de investigaciones sobre este arte, hubo varios eventos importantes, como una exposición de la laca namban organizada en el Tokyo National Museum, en I969 ${ }^{184}$ y la Exposición Universal de Osaka en I970. En esta última celebración, el Museu Nacional de Arte Antiga de Lisboa presentó un atril de laca que ostentaba el emblema jesuítico, el cual causó un gran impacto a los japoneses e hizo tomar conciencia de la importancia de las piezas de laca namban fuera del

ı80. Mitsuomi Yamaguchi, "Nihon ni okeru yōfū kenchiku dōnyū katei no kenkyū", tesis doctoral en Ingeniería, Universidad de Tokio, I970, p. 48.

I8I. Theo H. Lunsingh Scheurleer, "Aanbesteding en verspreiding van Japansch lakwerk door de Nederlanders in de zeventiende eeuw", Jaarverslagen Oudheidkundig Genootschap, vol. 83, I94I, pp. 54-74.

I82. Martha Hagensen Boyer, Japanese Export Lacquers from the Seventeenth Century in the National Museum of Denmark, Copenhague, National Museum, 1959, p. 64.

183. Yoshirō Kitamura, Namban bijutsu, 2 vols., Osaka, Namban Bunkakan, 1968.

I84. Kaori Hidaka, Ikoku no hyōshō: kinsei yushutsu shikki no sōzōryoku, Tokio, Brüche, 2008, p. IO. 
país. Por ende, el Ministerio de Educación de Japón envió a especialistas como Yoshimura a investigar las piezas conservadas en Europa entre 1972 y $1973 .{ }^{185}$

Autores destacables en la investigación de la laca namban en el último tercio del siglo xx fueron Hirokazu Arakawa (I929-), Yuzuru Okada (i91 II98I), Motoo Yoshimura (1933-), Akio Haino (1942-) y Kumiko Doi. Éstos se aproximaron a las obras distinguiendo las de exportación de las de consumo interno. Así, Arakawa propuso la forma de clasificar la laca namban en dos grupos: el primero incluía las obras realizadas de acuerdo con el encargo y gusto de los ibéricos, como las piezas de liturgia católica (hostiarios, retablos y atriles) y los objetos utilizados por los occidentales en la vida cotidiana, mientras que en el segundo agruparon las hechuras producidas para el consumo doméstico civil. A su juicio, pudo haberse creado un patrón de la laca de exportación de acuerdo con el gusto y las necesidades de los occidentales, además de que estas obras debieron de presentar un sello de lo "japonés". También el autor aseveró que lo que llaman hoy "laca namban" incluía piezas exportadas aun después de cortar las relaciones diplomáticas y comerciales con los países católicos en I639, dado que las piezas de uso civil se siguieron exportando mediante la Compañía Holandesa de las Indias Orientales. ${ }^{86}$ Por tanto, no se podía separar de manera tajante el concepto de la cultura namban, "bárbaros del sur", que alude generalmente al fenómeno dado por medio del contacto con los ibéricos, de la cultura kōmō, "cabello rojo", que en teoría se refiere a la cultura dada a través de los intercambios con los holandeses, llamados "cabello rojo" por los japoneses.

Asimismo, Arakawa equiparó las técnicas y los motivos de la laca entre las piezas dirigidas a los occidentales y a los japoneses. En los objetos del "primer grupo" se empleaban simultáneamente las técnicas de hira-makie, ${ }^{187}$ enashiji, ${ }^{188}$

I85. Motoo Yoshimura, "Namban bijutsu to kōgei ni tsuite", en Sōrin to namban bunka —Tsukumi-shi shüshù Io nen no seika-Tsukumi City's Namban Art Collection - Special Exhibition Celebrating a Decade of Acquisitions—, Tsukumi, Ōita, Tsukumi City Office, 1996, p. 8.

I86. Hirokazu Arakawa, Namban shitsugei, Tokio, Bijutsu Shuppansha, I97I, p. I29.

I87. Hira-makie, 平蒔絵: se trata de la técnica de dibujar motivos con laca cruda, aplicar polvos de oro y plata sobre ello antes de que se seque y una vez que esté seco, aplicar laca sólo en la parte que tiene motivos y pulirla al final.

I88. Enashiji, 絵梨地: se trata de la técnica de aplicar polvos de nashiji, “textura de pera”, ya que se parece al motivo de cáscara de pera. 
makizuri, ${ }^{189}$ harigaki ${ }^{190}$ y raden ${ }^{191} \mathrm{El}$ raden del "primer grupo" presentaba en mayor medida la influencia de la técnica coreana, aunque en la laca namban casi no se resquebraba la superficie de concha. Lo anterior implicaba la simplificación de la técnica, ya que en la obra que ostentaba conchas resquebradas se apreciaba también un mejor tratamiento en otros detalles. Por otra parte, en la imprimatura de la laca del "primer grupo" se empleaba una laca importada del sudeste de Asia, menos costosa y de baja calidad. Por lo mismo, las figuras aplicadas sobre la superficie se desprendían con facilidad, de aquí que, para las piezas de exportación, se empleó una laca importada y económica y además se produjo de manera masiva en un corto espacio de tiempo. Ello hizo que dichas piezas no tuvieran un acabado tan fino. ${ }^{192}$ Desde mi punto de vista, cabría matizar esta afirmación del autor, ya que entre las piezas de exportación hubo obras de diferentes calidades.

Respecto a las piezas de laca del "segundo grupo", el mismo estudioso observó la aplicación de las técnicas maki-e, ${ }^{193}$ raden, urushi-e ${ }^{194}$ y mitsuda-e ${ }^{195}$ Asimismo, señaló diferencias en los motivos empleados: en las obras del "primer grupo" se presentaban símbolos cristianos, representaciones pictóricas tanto humanas como vegetales y animales, motivos geométricos y sarmientos, mientras que en las hechuras del "segundo grupo" aparecían los "bárbaros del sur", perro occidental, elefante, objetos traídos de fuera, rayado, cruz con flor, entre otros. Referente al motivo rayado, el autor consideró que debió haber sido tomado de los motivos de los textiles importados. ${ }^{196}$

Otra aportación de Arakawa fue asociar la técnica de producción simplificada y masiva de la laca namban con la técnica del maki-e, empleada en el

I89. Makizuri, 蒔摺: técnica de limar con algodón remojado con laca cruda después de realizar el trabajo de maki-e y posteriormente pulirlo con polvos.

I90. Harigaki, 針描: técnica de aplicar polvos sobre la superficie y dibujar líneas rascando con aguja cuando la laca esté seca de manera moderada.

I9I. Raden, 螺鈿: técnica de incrustar conchas cortadas o pegarlas sobre la superficie.

192. Arakawa, op. cit., pp. I3 I y I36-I39.

193. Maki-e: técnica de dibujar sobre la superficie laqueada aplicando polvos de oro y plata antes de que se seque.

194. Urushi-e: técnica de pintar con las lacas de colores bermellón, negro, amarillo, verde y ocre.

195. Mitsuda-e: técnica de pintar mezclando pigmentos, aceite y un secante del monóxido de plomo amarillo $(\mathrm{PbO})$.

196. Arakawa, op. cit., pp. I43-I 48 y I5I-I52. 
templo budista Kōdaiji, mausoleo de Hideyoshi, en Kyoto. De esta forma, postuló el aprovechamiento de las técnicas y sistemas de producción nativos. Las relaciones con el sistema laboral, las técnicas, los métodos de elaboración y los motivos empleados en las obras de la escuela de laca Kōdaiji fueron profundizadas por Yoshimura y Haino. ${ }^{197}$

Doi, por su parte, sistematizó la tipología de los retablos de laca y realizó un análisis formal e iconográfico. En su opinión, dichas piezas compartían características con el grupo de laca de exportación. Es decir, a diferencia de las piezas de uso doméstico, los retablos no presentaban una coherencia de estación en los motivos, puesto que se mezclaban figuras que aludían a distintas estaciones al mismo tiempo. Además, se empleaba en abundancia la técnica de raden y un marco decorado con motivos geométricos y vegetales conforme al gusto de los occidentales. ${ }^{198}$

En tiempos recientes, Oliver Impey (1936-2005), especialista en los intercambios transoceánicos del arte que durante décadas estuvo investigando la laca namban, publicó Japanese Export Lacquer I580-I850 (2005) con la colaboración de Christiaan Jörg. La teoría de Impey se distinguió por la concepción lineal-evolucionista y la visión esquemática de interpretar el fenómeno artístico. En efecto, consideró que las producciones de laca destinadas a la exportación se transformaron en la secuencia cronológica de "estilo namban", "estilo intermedio" y "estilo pictórico". Sin embargo, la novedad de este autor fue proponer que la laca namban se apropió de las tradiciones derivadas de distintas regiones asiáticas: Japón, Corea y Guyarat, en India. Lo anterior se debió a que para los europeos, lo atractivo de la laca japonesa no radicó en su diseño original en sí, sino en las cualidades del material, que no se conseguía en Occidente; ésta fue la razón por la cual se presentaron diversas influencias extranjeras de acuerdo con el gusto y la necesidad funcional de los consumidores europeos. ${ }^{199}$ Asimismo, se ha indicado la semejanza estructural entre los atriles para el Corán y los del arte kirishitan. Ambas hechuras son plegables, aunque la manera de colocar el texto sagrado es distinta: el Corán abierto se sostie-

197. Motoo Yoshimura y Akio Haino, Ködaiji maki-e, Tokio, Kōdansha, I98I.

198. Kumiko Doi, "Makie Seigan — Research Material on Lacquerware for Exportation of Momoyama Period", en Shikkoushi: History of Lacquer Art, Tokio, Kin No Kyushitsu ni Tsuite, vol. II, I988, p. 2 I.

199. Oliver Impey y Christiaan Jörg, Japanese Export Lacquer 1580-I850, Ámsterdam, Hotei, 2005, pp. 77-8I. 
ne de forma horizontal utilizando los lados del atril, mientras que la Biblia se coloca de manera vertical apoyándose sobre un solo lado del atril. ${ }^{200}$

Kaori Hidaka (196I-) desarrolló la idea propuesta por Impey y postuló que la laca namban de exportación presentaba en mayor medida la influencia del arte islámico e hindú —en especial, guyaratí — más que la del arte chino y coreano. ${ }^{20 I} \mathrm{La}$ aportación de esta autora fue analizar la dimensión simbólica de las obras, teniendo presente la conformación de la imagen de Japón ante el mundo a través de la identidad artística manifestada en las piezas de laca. En su opinión, el trasfondo en que el arte de laca llegó a ser símbolo de Japón en Occidente tuvo que ver con la imagen de Cipango, puesto que la pintura dorada sobre la superficie de laca negra fue una hechura adecuada para remitir a aquella isla mítica de oro señalada por Marco Polo. ${ }^{202}$ Además, la laca namban de exportación ostentaba herencias artísticas de diferentes regiones de Asia más que elementos derivados del arte europeo y japonés, lo cual fue resultado de haber plasmado la imagen de "Oriente" tal como era entendida por los europeos. En otras palabras, se construyó una imagen ficticia de lo "japonés" debido a que a los occidentales les era más fácil comprender la idea de "Oriente" mediante la muestra de tradiciones visuales del Medio Oriente o la India que ya conocían. Así, Hidaka advirtió que la idea de "país extranjero" o "gusto exótico" ha descansado sobre la ambigüedad conceptual; esto no fue característica singular de la laca namban, dado que lo mismo sucedió con la chinoiserie en el mundo occidental. ${ }^{203}$

Como se observa en el estudio anterior, una de las metas académicas de nuestro tiempo es ahondar en el arte kirishitan desde el punto de vista global, ya que la naturaleza de este arte no se conformaba sólo con las herencias artísticas japonesas y europeas, sino que se nutría del legado cultural de toda una amplia región - Medio Oriente, Asia y América - que estuvo conectada a través de las rutas comerciales y evangélicas de la época. Asimismo, haría falta todavía estudiar la integración en el culto local, las transformaciones iconográficas, la simplificación formal y la creatividad del arte de los kirishitan

200. Tsuyoshi Yamazaki, Umi wo watatta Nihon shukki I: I6-I7 seiki, Tokio, Shibundō, 200I, p. 30.

20I. Hidaka, op. cit., pp. 60-6I.

202. Ibidem, p. 37.

203. Ibidem, pp. 60-6I, II3 y I33. 
ocultos, ${ }^{204}$ ya que hasta la fecha se ha estudiado sólo desde el punto de vista etnológico. ${ }^{205}$

En el ámbito de la restauración, la aplicación de las tomas fotográficas de ultravioleta fluorescente y de rayos $\mathrm{X}$ y el análisis químico de los materiales han hecho cambiar de manera radical la forma de interpretar la pintura kirishitan. En efecto, se ha esclarecido el origen mineral de diferentes pigmentos empleados en dicho arte. ${ }^{206} \mathrm{La}$ aplicación de métodos interdisciplinarios es otra característica de las investigaciones de nuestro tiempo. En especial, en Nagasaki y en Ōita (antiguo Bungo) se han realizado excavaciones arqueológicas y se han rescatado tejas con cruz floral, ${ }^{207}$ medallas ${ }^{208}$ y cuentas del rosario. ${ }^{209}$ Estos vestigios han sido analizados no sólo desde el punto de vista formal-iconográfico, sino que han sido sometidos al análisis científico para identificar composiciones químicas, a partir de las cuales se ha dilucidado la posible procedencia de estos objetos. ${ }^{210}$

En suma, nuevas metodologías y aproximaciones han transformado de manera radical las interpretaciones del arte kirishitan. La narrativa de la primera mitad del siglo pasado se caracterizó por una postura eurocéntrica, ya que las obras católicas japonesas se juzgaron con criterios basados en el arte occidental. Ello hizo menospreciar el valor artístico de las expresiones nativas. Sin embargo, es de notar que esta característica no fue exclusiva de la historiografía del arte japonés, sino también de la del arte dado fuera del contexto europeo, como el caso del arte novohispano en América.

204. Sakamoto, "Namban Art and European-style Painting", op. cit., pp. 4-5 y 36.

205. Ken'ichi Tanigawa, Sacred Paintings of Hidden Christians, con fotos de Tadashi Nakajō, Tokio, Shōhakukan, I999.

206. Ichirō Watanabe, "Restoration Report: 'Portrait of Christ', by Unknown Painter", Institute of Painting Technology. Technical Bulletin, vol. I5, I999-2000, pp. IO-I I; Jun'ichi Miyata, "Restoration Report: 'Portrait of Christ', by Unknown Painter", en ibidem, pp. I2-I3. 207. Katsuyama-machi iseki..., op. cit.

208. Bungo Funai I, Ōita, Ōita-ken Kyōiku-chō Maizō Bunkazai Center, 2005; Bungo Funai 2, Ōita, Ōita-ken Kyōiku-chō Maizō Bunkazai Center, 2005; Bungo Funai 4, Ōita, Ōita-ken Kyōiku-chō Maizō Bunkazai Center, 2006; Bungo Funai 6, Ōita, Ōita-ken Kyōikuchō Maizō Bunkazai Center, 2007.

209. Hitomi Asada y Kōichi Gotō, "A Study of 'Contas'”, Junshin Journal of Human Studies, núm. I4, marzo de 2008, pp. II5-I46.

210. Bungo Funai 2, op. cit., pp. 347-354; Bungo Funai 4, op. cit., pp. 205-219; Haruki Konno, "Fukyoki ni okeru medai no kenkyū: I6 seiki kōhan kara I7 seiki zenhan ni kakete", Busshitsu Bunka Material Cultures, núm. 82, noviembre de 2006, pp. 25-68. 
Asimismo, las discusiones en la historia del arte a nivel internacional repercutieron en la comprensión del arte católico en distintas partes del mundo. De esta forma se realizó una redefinición del impacto de la Reforma católica y del "manierismo" en la década de 1970, tanto en el ámbito académico japonés como en el americano. Incluso el debate internacional en torno al "estilo jesuítico", el cual se ha vinculado con los conceptos del "arte de la Contrarreforma", "arte propagandístico" y "manierismo", ${ }^{211}$ repercutió en la comprensión del arte kirishitan.

Hoy las investigaciones se caracterizan por aplicar tecnología de punta y métodos interdisciplinarios a nivel internacional. En lugar de generalizar el fenómeno esquematizándolo en taxonomías estilísticas y quedarse en discusiones meramente teóricas, se tiende a realizar un análisis de manera global entrecruzando los conocimientos de distintas áreas, lo cual ha conducido a esclarecer las características concretas de las obras. \$\$

21 I. Evonne Anita Levy, Propaganda and the Jesuit Baroque, Berkeley, University of California Press, 2004, pp. 36-40.

* Artículo recibido el is de noviembre de 20I0; aceptado el 30 de marzo de 20 I I. 